\title{
SRPSKA DEMOKRATSKA STRANKA OD KONSTITUIRANJA PRVOG VIŠESTRANAČKOG SABORA DO POČETKA SRPSKE POBUNE U HRVATSKOJ U KOLOVOZU 1990.
}

\author{
Domagoj KNEŽEVIĆ \\ Hrvatski institut za povijest \\ Zagreb, Hrvatska
}

\author{
UDK: $329(497.5)$ SDS \\ DOI: https://doi.org/10.21857/ypn4oc8ko9 \\ Pregledni rad \\ Prihvaćeno: 12. siječnja 2018.
}

Tema ovoga rada je djelovanje Srpske demokratske stranke u razdoblju od konstituiranja prvog višestranačkog Sabora pa sve do početka srpske pobune u kolovozu 1990. Također, u radu se razmatra osnivanje stranačkih odbora i neuspješan pokušaj širenja u drugim republikama SFRJ te uloga vodstva i članova stranke u početku srpske pobune u Hrvatskoj. Rad je nastao na temelju dostupnih arhivskih dokumenata, svjedočenja i medijskih istupa stranačkih vođa.

Ključne riječi: Srpska demokratska stranka, pobuna, Jovan Rašković, Milan Babić, Knin, pobuna.

„Osjećam se odgovornim zato što sam izvršio pripremu za ovaj rat, iako tu pripremu nisam vršio vojno, kao neko ko vidi rješenje u ratu, ali da nije bilo podizanja emocionalne vatre u srpskom narodu, ne bi bilo ni toga. U stvari, moja stranka i ja lično smo zapalili fitilj srpstva ne samo u Hrvatskoj.“

Jovan Rašković, Vreme, 27. 1. 1992.

\section{UVOD}

Nakon dugogodišnje komunističke vladavine, na prvim hrvatskim demokratskim izborima u travnju i svibnju 1990. premoćno je pobijedila Hrvatska demokratska zajednica (HDZ) predvođena Franjom Tuđmanom. Trodomni demokratski Sabor konstituiran je svečanom sjednicom koja je održana 30. svibnja 1990. Sukladno rezultatima izbora, na čelna mjesta Socijalističke Republike Hrvatske (SRH) izabrani su članovi HDZ-a. Za predsjednika Predsjedništva SRH izabran je Franjo Tuđman, za predsjednika Izvršnog vijeća SRH izabran je Stjepan Mesić, dok je za predsjednika Sabora SRH izabran Žarko Domljan. Međutim, zastupnici Srpske demokratske stranke (SDS) nisu nazočili svečanoj sjednici zbog navodnog napada na njihova člana Miroslava Mlinara u Benkovcu. Navedeni bojkot rezultirao je time da na mjesto potpredsjednika Sabora nije izabran član SDS-a Jovan Opačić. Navedena funkcija bila je političkim dogovorom predviđena za zastupnika srpske nacionalnosti. Osim 
zastupnika SDS-a, svečanoj sjednici također nije nazočio zagrebačko-ljubljanski mitropolit Srpske pravoslavne crkve (SPC) Jovan. No, navedeni izostanci u stvari su bili reakcija nezadovoljstva zbog izborne pobjede HDZ-a. U čemu je bio problem? U političkom programu $\mathrm{HDZ}$-a srpsko je pitanje bilo tretirano kao bitno političko pitanje. Na osnovi toga, iz HDZ-a se nudila suradnja budućim legitimnim demokratskim predstavnicima Srba u Hrvatskoj te zaštita njihovih manjinskih prava na najvišem nivou. Međutim, odricalo im se pravo da kao manjinska zajednica odlučuju o pitanjima koja se tiču suverenosti Hrvatske i hrvatskog naroda. Usto, izostanak srpskih predstavnika bio je nastavak raznih incidenata koji su počeli nakon izborne pobjede HDZ-a. Među tim incidentima najveći je ipak bio oduzimanje oružja Teritorijalne obrane (TO) SRH od strane JNA, koje je provedeno uz političku podršku Srbije. ${ }^{1}$ Izgleda da to nije bilo sve. Prema najnovijem svjedočenju Josipa Manolića, vrh JNA je uoči konstituiranja Sabora zatražio od predsjednika SKH - SDP-a Ivice Račana da ih službeno pozove na intervenciju u Hrvatskoj, nakon koje bi uveli vojnu upravu. ${ }^{2}$ Međutim, učestali incidenti nisu bili neočekivani. Pobjedom HDZ-a na izborima propao je aktualni plan vodstva Srbije i vrha JNA da preurede SFRJ sukladno svojim interesima. Stoga je predsjednik SR Srbije Slobodan Milošević odmah nakon demokratskih izbora predložio vrhu JNA da Sloveniju i Hrvatsku istjera silom iz zajedničke države, ali uz amputaciju hrvatskih područja na kojima žive Srbi. ${ }^{3}$

Službeni rezultati SDS-a na izborima nisu bili dobri. Hrvatski Srbi uglavnom su dali povjerenje kandidatima iz SKH-SDP-a. Unatoč snažnom nacionalnom naboju na njihovim predizbornim skupovima, politički se rad SDS-a tijekom izborne kampanje odvijao slobodno. Član vodstva SDS-a Jovan Opačić svjedočio je da su se dogodila samo dva manja incidenta. U stvari, više je napada bilo zabilježeno na izbornim skupovima HDZ-a, među kojima je bio i pokušaj atentata na F. Tuđmana u Benkovcu. ${ }^{4} \mathrm{Na}$ kraju je SDS imao pet zastupnika u Saboru, što je predstavljalo 1,4 \% mandata. Izabrani zastupnici SDS-a bili su: Jovan Opačić, Dušan Zelembaba, Radoslav Tanjga, Ratko Ličina i Dušan Ergarac. Na lokalnom nivou SDS ostvario je apsolutnu pobjedu u samo tri općine: Donji Lapac, Gračac i Knin, u kojima je bez problema konstituirao lokalnu vlast. Ključna osoba u osnivanju i stvaranju stranačke ideološke platforme SDS-a

1 Domagoj KnežEvić, Hrvatska demokratska zajednica, od osnivanja do raskida s Jugoslavijom, Doktorska disertacija, Sveučilište u Zagrebu, Zagreb, 2015., 161 - 225.

2 Josip Manolić, Špijuni i domovina: moja borba za suverenu i socijalnu Hrvatsku, Zagreb, 2016., $239-242$.

3 Borisav Jović, Posljednji dani SFRJ, Kragujevac, 1996., 159 - 161.

4 Jovan Opačıć, Tragedija krajiških Srba, Beograd, 2012., 111 - 115. 
bio je neuropsihijatar dr. Jovan Rašković iz Šibenika. On je bio dugogodišnji prijatelj srbijanskog književnika i člana Srpske akademije nauka i umetnosti (SANU) Dobrice Ćosića, koji ga je i potaknuo na osnutak SDS-a. No, u kratkom vremenu kao važna politička osoba u vodstvu SDS-a nametnuo se kninski dr. dent. med. Milan Babić, koji je tijekom osnivanja SDS-a još uvijek bio član SKH. Član SDS-a postao je tek uoči demokratskih izbora. Unatoč tomu, s potporom vijećnika SDS-a izabran je na mjesto predsjednika Skupštine općine (SO) Knin, koje je bilo jedno od najvažnijih stranačkih mjesta izborenih na izborima. No, Babićev izbor izazvao je prvi veliki stranački raskol u SDS-u nakon što se tom rješenju usprotivio J. Opačić. ${ }^{5}$

\section{OSNIVANJE ODBORA SDS-A U HRVATSKOJ NAKON IZBORA}

Nakon konstituiranja hrvatskih demokratskih vlasti, SDS je u Hrvatskoj nastavio $s$ osnivanjem stranačkih odbora. Na području Korduna novi mjesni odbor SDS-a u općini Karlovac osnovan je 2. lipnja 1990. u mjestu Krnjak. Za predsjednika odbora izabran je Milan Kresojević. Općinski odbor SDS-a u Slunju također je osnovan 2. lipnja 1990. Za predsjednika odbora izabran je Đuro Alinčić. ${ }^{6} \mathrm{Na}$ području Like osnovani su novi mjesni odbori u općini Gospić. Odbor za mjesta Vrebac, Barlete i Pavlovac osnovan je 10. lipnja $1990 .{ }^{7}$ Novi mjesni odbor osnovan je 30. lipnja 1990. u Ličkom Osiku. ${ }^{8}$ Općinski odbor SDS-a u općini Otočac osnovan je 12. srpnja 1990. u mjestu Zalužnica. ${ }^{9} \mathrm{Na}$ području Gorskog kotara općinski odbor SDS-a osnovan je 3. lipnja 1990. u Gomirju u općini Vrbovsko. Za predsjednika odbora izabran je Lazo Mamula. ${ }^{10} \mathrm{Na}$ području Hrvatskog primorja osnovan je 7. srpnja 1990. općinski odbor SDS-a u Rijeci. Za predsjednika odbora izabran je Dragan Čolović. ${ }^{11}$

Uslijedio je i niz osnivanja odbora SDS-a u Slavoniji, Baranji i zapadnom Srijemu. Na tom području SDS je do tada imao vrlo malo osnovanih odbora. Po vlastitom svjedočenju, jedan od glavnih inicijatora za osnivanje tamošnjih

5 Domagoj Knežević, Srpska demokratska stranka od osnivanja do konstituiranja prvog višestranačkog Sabora, Časopis za suvremenu povijest, sv. 43, br. 1, Zagreb, 2011., 7 - 24.

6 Rašković prigovara Saboru, Večernji list, br. 9622, 4. 6. 1990., 6. Vidi također u Mile Pecić, Zakopani dnevnik: dramatična zbivanja 1990. - 1991. u slunjskom kraju, Zagreb, 2003., 29 - 30.

Marija Sentić, Kronologija Republike Hrvatske 1990.-1998., Zagreb, 2015., 56.

Ne damo našu ZO, mi ćemo je širiti, Večernji list, br. 9649, 1. 7. 1990., 4.

Upoznali smo i zmiju ispod kamena, Politika, br. 27575, 14. 7. 1990., 8.

10 Promjene potiču srpski narod, Novi list, br. 151, 4. 6. 1990., 2.

11 Ne priznajemo grupni suverenitet, Novi list, br. 184, 8. 7. 1990., 6. 
odbora bio je Borivoj Savić iz Vukovara, koji je uspostavio prve kontakte $s$ vodstvom SDS-a. ${ }^{12}$ Nakon izbora prvi općinski odbor SDS-a u Slavoniji osnovan je 9. lipnja 1990. u Grubišnom Polju. Za predsjednika odbora izabran je Branko Popović. ${ }^{13}$ Općinski odbor SDS-a u Podravskoj Slatini osnovan je 10. lipnja 1990. Za predsjednika odbora izabran je Milun Karadžić. ${ }^{14}$ I općinski odbor SDS-a u Vukovaru osnovan je 10. lipnja 1990. Za predsjednika odbora izabran je Goran Hadžić. ${ }^{15}$ Prema kasnijim svjedočenjima, G. Hadžić je kao suradnik Uprave bezbednosti JNA i kasnije Službe državne bezbednosti (SDB) Srbije bio idealan kandidat za tu funkciju. ${ }^{16}$ Općinski odbor SDS-a u Pakracu osnovan je 16. lipnja 1990. Za predsjednika odbora izabran je Veljko Džakula. ${ }^{17}$ Odbor SDS-a u Velikim Bastajima, mjestu u općini Daruvar, osnovan je 8. srpnja 1990. Za predsjednika odbora izabran je Željko Bosanac. ${ }^{18}$

Na području općine Osijek osnivanje mjesnih odbora SDS-a počelo je u lipnju 1990. Prvi mjesni odbor osnovan je 17. lipnja 1990. u Silašu. ${ }^{19}$ Sljedeći mjesni odbor osnovan je 24. lipnja 1990. u Tenji. Za predsjednika odbora izabran je Žarko Čubrilo. ${ }^{20}$ Novi mjesni odbor u općini Osijek osnovan je 8. srpnja 1990. za mjesta Sarvaš i Bijelo Brdo. ${ }^{21}$ Prvi odbor SDS-a u Baranji osnovan je 7. srpnja 1990. u Bolmanu, mjestu u općini Beli Manastir. Za predsjednika odbora izabran je Milovan Vakanjac. ${ }^{22}$ Općinski odbor SDS-a u Belom Manastiru osnovan je 22. srpnja $1990 .^{23}$ I mjesni odbor SDS-a u Boboti, mjestu u općini Vukovar, osnovan je 22. srpnja $1990 .^{24}$

U Okučanima, mjestu u općini Nova Gradiška, odbor SDS-a osnovan je 27. srpnja 1990. Za predsjednika je izabran Stevan Stančić. ${ }^{25}$ Općinski odbor SDS-a

12 Sudski spisi Međunarodnog kaznenog suda za bivšu Jugoslaviju u Den Haagu (MKSJ), StanišićSimatović (IT-03-69), Svjedočenje Borivoja Savića, 6. 7. 2009., 10 - 12, posjet ostvaren 14. 9. 2016., http://icr.icty.org/bcs/defaultb.aspx.

13 Jovan Rašković u Grubišnom Polju, Grubišnopoljski list, br. 75., 29. 6. 1990., 2.

14 Zajedništvo, bilo i ostalo sudbina, Glas Slavonije, br. 13836, 11. 6. 1990., 2.

15 Ne želimo nove grobove Glas Slavonije, br. 13836, 11. 6. 1990., 2 - 3.

16 Ljuban KARAN, Bio sam oficir KOS-a, Beograd, 2006., 79 - 80, 95 - 102.

17 Hrvatska je i naša domovina, Večernji list, br. 9635, 17. 6. 1990., 3.

18 Hrvatska (HR) - Hrvatski memorijalno-dokumentacijski centar Domovinskog rata (HMDCDR), Političke stranke i pokreti u Republici Srpskoj Krajini (PSPRSK), Serija Srpska demokratska stranka (SSDS), kut. 4.

19 Prvi mjesni odbor u SDS-a u osječkoj općini, Večernji list, br. 9636, 18. 6. 1990., 4.

20 Ne žele šoviniste u svojim redovima, Glas Slavonije, br. 13848, 25. 6. 1990., 6.

21 Traže srpsku televiziju, Glas Slavonije, br. 13860, 9. 7. 1990., 6.

22 Osnovan odbor SDS-a u Baranji, Vjesnik, br. 15734, 9. 7. 1990., 2.

23 Zahtjevi za autonomijom, Glas Slavonije, br. 13873, 24. 7. 1990., 16.

24 Štit i mač Srba, Glas Slavonije, br. 13872, 23. 7. 1990., 12.

25 HR-HMDCDR-PSPRSK-SSDS, kut. 4. 
Slavonska Požega osnovan je 28. srpnja 1990. u mjestu Sloboština. Za predsjednika odbora izabran je Milutin Ivanović. ${ }^{26} \mathrm{U}$ Mirkovcima, mjestu u općini Vinkovci, osnovan je 9. kolovoza 1990. odbor SDS-a Mirkovci - Vinkovci. Za predsjednika odbora izabran je Miroslav Ćirić. ${ }^{27} \mathrm{Na}$ području Slavonije i Baranje počelo je i regionalno organiziranje stranke. Regionalni odbor SDS-a za Baranju osnovan je 13. kolovoza 1990. Za predsjednika odbora izabran je Vojislav Vukčević iz Osijeka. ${ }^{28}$ Regionalni odbor SDS-a za Slavoniju osnovan je 16. kolovoza 1990. Za predsjednika je izabran Ilija Šašić iz Podravske Slatine. ${ }^{29}$

I u Dalmaciji je nastavljeno s osnivanjem odbora SDS-a. U Smokoviću, mjestu u općini Zadar, osnovan je 16. lipnja 1990. mjesni odbor SDS-a. ${ }^{30}$ U Kuli Atlagić, mjestu u općini Benkovac, mjesni odbor SDS-a osnovan je 23. lipnja 1990.31 Inicijativni općinski odbor SDS-a za općinu Drniš osnovan je početkom srpnja 1990. Uz Drniš, odbor je trebao pokrivati i mjesta u drniškoj općini: Velušić, Varoš, Kričke, Razvođe, Žitnić i Bobodol. Za predsjednika odbora izabran je Dušan Rašković. ${ }^{32}$

Prvi odbor osnovan nakon izbora na području Banovine bio je općinski odbor SDS-a u Petrinji koji je osnovan 23. lipnja 1990. Za predsjednika odbora izabran je Rajko Jasić. ${ }^{33}$ U mjestu Drljače kraj Sunje osnovan je 30. lipnja 1990. prvi odbor SDS-a u općini Sisak. Za predsjednika je izabran Boro Gvozden. ${ }^{34} \mathrm{U}$ općini Hrvatska Kostajnica SDS je svoj program predstavio već u ožujku 1990., ali je rad stranke ubrzo prestao. ${ }^{35}$ Ponovno aktiviranje općinskog odbora SDS-a u Hrvatskoj Kostajnici dogovoreno je 27. srpnja $1990 .{ }^{36}$ Za predsjednika odbora je 2. kolovoza 1990. izabran Željko Arbutina. ${ }^{37}$

Usporedno s osnivanjem stranačkih odbora, nastavljeno je $s$ jačanjem unutarnjeg ustroja stranke. Na tragu ustroja drugih stranaka, osnovan je 24. lipnja 1990. u Kninu inicijativni odbor za osnivanje omladinske organizacije

\footnotetext{
26 Osnovan SDS za Slavonsku Požegu, Večernji list, br. 9677, 29. 7. 1990., 4.

Mržnja se mora stišati, Glas Slavonije, br. 13888, 10. 8. 1990., 15.

Za međustranačku suradnju, Glas Slavonije, br. 13891, 14. 8. 1990., 12.

Spremni za sve, Glas Slavonije, br. 13894, 17. 8. 1990., 1.

30 Republika Hrvatska i Domovinski rat 1990.-1995., Knjiga 2, Dokumenti institucija pobunjenih Srba u RH 1990.-1991., Zagreb, Slavonski Brod, 2007., 28 - 30.

31 Republika Hrvatska i Domovinski rat 1990.-1995., Knjiga 2, Dokumenti institucija pobunjenib Srba u RH 1990.-1991., 30 - 31.

32 Privatnici bi otkupili Dalstroj?, Šibenski list, br. 1392, 7. 7. 1990., 4.

33 Da Ivica i Jovica ne žive u strahu, Jedinstvo, br. 2138, 28. 6. 1990., 2.

34 Živjeti u slozi, Jedinstvo, br. 2139, 5. 7. 1990., 2.

35 Miting i u Zagrebu, Večernji list, br. 9554, 26. 3. 1990., 4.

36 HR-HMDCDR-PSPRSK-SSDS, kut. 4.

37 HR-HMDCDR-PSPRSK-SSDS, kut. 4.
} 
SDS-a. Prema zamisli, omladinska organizacija trebala je biti organizirana od mjesne do općinske razine te se baviti stvarima od interesa mladih. ${ }^{38}$ Osim toga, vodstvo SDS-a započelo je sa stvaranjem boljih materijalnih i tehničkih uvjeta za stranački rad kroz preuzimanje nekadašnje društvene imovine u vlasništvu organizacija SK. ${ }^{39}$

\section{NEUSPJEŠAN POKUŠAJ DALJNJEG ŠIRENJA SDS-A U OSTALIM REPUBLIKAMA SFRJ}

Do demokratskih izbora u Hrvatskoj SDS je bio osnovao svoje prve odbore u Srbiji i Sloveniji. Odbor u Beogradu osnovan je 12. svibnja 1990., dok je odbor u Novom Mestu osnovan 19. svibnja $1990 .{ }^{40}$ Nakon izbora nastavljeno je s osnivanjem odbora SDS-a u Srbiji i Vojvodini. Prema osobnim svjedočenjima, inicijatori osnivanja odbora SDS-a u Vojvodini bili su Ilija Petrović i Kosta Hadži. Odbor SDS-a osnovan je 17. lipnja 1990. u Novom Sadu. Međutim, među domaćinima skupa javilo se određeno nezadovoljstvo nakon osnivanja. Prema I. Petroviću, veći dio vodstva stranke smatrao je novosadski skup samo „rekreacijom“ jer su puno više očekivali od odbora SDS-a u Beogradu. Navedena pretpostavka temeljila se na procjeni broja doseljenih hrvatskih Srba koji su tada živjeli u tim gradovima. ${ }^{41}$ Skup je imao još svojih specifičnosti. U svom istupu J. Rašković napao je S. Miloševića zbog odugovlačenja s provedbom demokratskih izbora te zbog represivnog odnosa prema srpskoj opoziciji. ${ }^{42}$ Bila je to bez sumnje Raškovićeva pogreška. Unatoč Raškovićevim negativnim razmišljanjima o Miloševiću, veliki broj članova SDS-a podržavao je tadašnju politiku čelnika Srbije. Shodno tomu, došlo je do unutarstranačke diferencijacije oko daljnjeg političkog nastupa u Srbiji. Dio članova stranke želio je nastupiti na višestranačkim izborima u Srbiji, dok se dio protivio zbog straha od zamjeranja S. Miloševiću. I M. Babić bio je protiv rada SDS-a u Srbiji jer je smatrao da još nisu dovoljno organizirani u Hrvatskoj. ${ }^{43}$ Krajem kolovoza 1990. na području

38 Zbog udžbenika - bojkot nastave?, Slobodna Dalmacija, br. 14210, 25. 6. 1990., 2.

39 Nikoga nismo uznemiravali, Večernji list, br. 9635, 17. 6. 1990., 3.

40 D. KNEŽEviĆ, Srpska demokratska stranka od osnivanja do konstituiranja prvog višestranačkog Sabora, $12-13$.

41 Ilija Petrović, Srpsko nacionalno vijeće Slavonije, Baranje i zapadnog Srijema, Novi Sad, 1994., 18 $-20$.

42 Neotuđiva prava srpskoga naroda, Slobodna Dalmacija, br. 14203, 18. 6. 1990., 32.

43 MKSJ, Babic (IT-03-72), Razgovor Milana Babića s istražiteljima vođen 28. 6. 2001., pristup ostvaren 15. 9. 2016., http://icr.icty.org/bcs/defaultb.aspx. 
Bačke u Vojvodini osnovana su tri nova odbora SDS-a. Ipak, čini se da je već pomalo zamirala inicijativa za daljnje osnivanje stranačkih odbora u Srbiji. No, to nije čudilo. Na sastanku početkom rujna 1990. S. Milošević osobno je poručio J. Raškoviću da na teritoriju Srbije „nema potrebe“ za političkim radom SDS-a. Ipak, rad SDS-a u Vojvodini nije mu toliko smetao pa je rekao da bi na sljedećim izborima u izbornim jedinicama na području Vojvodine SDS mogao istaknuti „pet - šest kandidata“. ${ }^{44}$ Navedene činjenice na kraju su sigurno doprinijele da rad SDS-a u Srbiji i Vojvodini bude neuspješan, što su pokazali i rezultati na prvim demokratskim izborima za Skupštinu Srbije u prosincu 1990. Na izborima je SDS izborio samo jedan mandat, i to u izbornoj jedinici Stara Pazova II - Pećinci. ${ }^{45}$

Usporedno je pokušano širenje SDS-a i na područje SR Bosne i Hercegovine (BiH). Prvi korak po tom pitanju napravili su J. Opačić i D. Zelembaba kada su sredinom lipnja 1990. u Titovom Drvaru predstavili program SDS-a svim zainteresiranim građanima u općinama Bosanske krajine. Na sastanku je dogovoreno i osnivanje inicijativnih odbora koji su u skorom vremenu trebali organizirati osnivačke skupštine SDS-a na cijelom teritoriju BiH. ${ }^{46}$ Unatoč službenoj zabrani njegova održavanja, prvi odbor SDS-a u BiH osnovan je 4. srpnja 1990. u Titovom Drvaru. Na skupu je bio nazočan J. Rašković te se okupilo oko četiri tisuće ljudi. ${ }^{47}$

Središnja osnivačka skupština SDS-a BiH održana je 12. srpnja 1990. u Sarajevu. Skup je otvorio Radovan Karadžić u svojstvu predsjednika središnjeg inicijativnoga odbora. I on je bio psihijatar po struci te je živio u Sarajevu. Tijekom skupa iznimno dugim pljeskom pozdravljeni su gosti iz kninskog SDS-a J. Rašković i J. Opačić. ${ }^{48}$ Javnosti je predstavljen i program SDS-a BiH. No, treba reći da je prvi program SDS-a BiH u usporedbi s prvim programom kninskog SDS-a ipak bio sadržajno slabiji. Imao je manji broj navedenih programskih točaka koje su bile puno slabije razrađene. ${ }^{49} \mathrm{U}$ izboru R. Karadžića za predsjednika SDS-a BiH presudnu je ulogu još jednom imao Dobrica Ćosić. Prvi kandidat za predsjednika SDS-a BiH bio je sarajevski pjesnik Vladimir Srebrov, koji je za svoju kandidaturu imao podršku J. Raškovića. Međutim, D. Ćosić uspio je nagovoriti J. Raškovića da odustane od podrške V. Srebrovu

$$
252 .
$$

46 Raškovićeva stranka osvaja Bosnu, Večernji list, br. 9634, 16. 6. 1990., 4.

47 Rašković promovisao stranku, Oslobodenje, br. 15101, 5. 7. 1990., 4.

48 Demokratski odgovor srpskoga naroda, Oslobođenje, br. 15109, 13. 7. 1990., 3.

49 Srpska demokratska stranka, Knin, 17. II. 1990., 1 - 16. Programska brošura u posjedu autora. 
i da zajedno podrže Karadžićevu kandidaturu. Ipak, problem je predstavljalo Miloševićevo protivljenje tom izboru, s obzirom na to da je lider Srbije smatrao R. Karadžića „pročetnički“ nastrojenom osobom. ${ }^{50}$

Nakon Sarajeva novi odbor SDS-a u BiH osnovan je u Trebinju 14. srpnja 1990. uz prisustvo R. Karadžića i J. Raškovića. Odbor je bio zamišljen da pokriva cijelu istočnu Hercegovinu. Skup je dobio naknadnu dozvolu održavanja iz lokalnog SUP-a. ${ }^{51}$ Odbor SDS-a u Mrkonjić Gradu osnovan je 2. kolovoza 1990. Na skupu su ponovno bili nazočni gosti iz kninskog SDS-a. Nakon ovog skupa donesena je i jedna bitna odluka za budućnost SDS-a BiH..$^{52}$ Što je bilo u sadržaju te odluke? U sadržaju odluke bio je dogovor J. Raškovića i R. Karadžića da svi odbori SDS-a osnovani u BiH ipak pripadnu organizaciji u BiH. Dogovor je bio potreban jer su glavnu ulogu u početnom osnivanju velikog broja odbora SDS-a po BiH imali J. Rašković i vodstvo kninskog SDS-a, a što je otvorilo problem hoće li pripadati kninskoj ili sarajevskoj središnjici SDS-a. Inače, politička karizma J. Raškovića bila je glavnim razlogom za brzo širenje SDS-a među Srbima u BiH. ${ }^{53}$ I Biljana Plavšić je kao jedna od čelnih ljudi SDS-a BiH tvrdila da su Raškovićeva politička razmišljanja bila glavni razlog zbog kojih je pristupila SDS-u, dok je budućeg predsjednika SDS-a BiH R. Karadžića vrlo slabo poznavala, iako su živjeli u istom gradu. Međutim, postignuti dogovor bio je realan. Broj Srba u BiH bio je puno veći nego u Hrvatskoj. Navedeno je značilo znatno veći kadrovski bazen i rad stranke u puno većim gradskim središtima nego što je Knin. ${ }^{54}$

Nakon postignutog dogovora s R. Karadžićem, J. Rašković sudjelovao je samo kao istaknuti gost u sljedećim osnivanjima odbora po BiH. Osnivački skup odbora SDS-a u Prijedoru održan je 2. kolovoza $1990 . .^{55}$ Novi hercegovački odbor SDS-a osnovan je 2. kolovoza 1990. u Gackom. ${ }^{56}$ Odbor SDS-a u Šipovu osnovan je 3. kolovoza 1990.57 Odbor SDS-a u Bosanskom Grahovu osnovan je također 3. kolovoza $1990 .^{58}$ Odbor SDS-a u Banjoj Luci osnovan je 4. kolovoza$$
54
$$

55 Zamjerke Skupštini SR BiH, Oslobođenje, br. 15130, 3. 8. 1990., 3.

56 Protiv Tita i Markovića, Oslobodenje, br. 15130, 3. 8. 1990., 3.

57 Napadi na Tita i Markovića, Oslobođenje, br. 15131, 4. 8. 1990., 4.

58 Poštovanje samo u federaciji, Oslobođenje, br. 15131, 4. 8. 1990., 4. 
$1990 .{ }^{59}$ Osnivački skup SDS-a za općine Bijeljina, Lopare i Ugljevik održan je 10. kolovoza 1990. u Bijeljini. ${ }^{60}$ Odbor SDS-a za Romaniju - Glasinac osnovan je 11. kolovoza 1990. u Sokolcu. ${ }^{61}$

\section{PREUZIMANJE VLASTI NA LOKALNOJ RAZINI I STVARANJE PARALELNIH INSTITUCIJA U HRVATSKOJ - POČETAK PREUZIMANJA VODSTVA MILANA BABIĆA U SDS-U}

Vrlo brzo nakon konstituiranja Sabora politika kninskog SDS-a počela je pokazivati svoje namjere. Na sjednici SO Knin održanoj 6.lipnja 1990. vijećnici su donijeli zaključak o potrebi stvaranja Zajednice općina (ZO) Sjeverne Dalmacije i Like te je van snage stavljena ranija općinska odluka o udruživanju kninske općine u ZO Dalmacije. Usto, nezakonito su si dodijelili mandat za utvrđivanje zakonskog nacrta odluke o osnivanju ZO Sjeverne Dalmacije i Like, koju su prema zamisli trebale tvoriti općine $s$ područja sjeverne Dalmacije i Like. ${ }^{62}$

Ubrzo nakon te odluke SDS je preuzeo lokalnu vlast u općini Obrovac. Bila je to četvrta općina u kojoj su preuzeli vlast te je za predsjednika SO Obrovac izabran član SDS-a Sergej Veselinović. Bilo je to ipak iznenađenje jer je SDS u toj općini imao slabe izborne rezultate. No, izbor $S$. Veselinovića omogućio je prijelaz vijećnika srpske nacionalnosti iz SKH-SDP-a u SDS. Suočeni s tom odlukom, vijećnici HDZ-a napustili su sjednicu, što je rezultiralo prekidom daljnjeg izbora preostalih općinskih čelnika. ${ }^{63}$ Odmah nakon izbora predsjednik SO Knin M. Babić upoznao je S. Veselinovića s inicijativom o stvaranju nove ZO ${ }^{64}$ Nasuprot tomu, u općini Benkovac nije došlo do konstituiranja lokalne vlasti jer u skupštini nitko nije imao apsolutnu većinu. Glavni razlog bio je izostanak velikog broja vijećnika koji nisu izabrani zbog raznih razloga. Usto, u skupštini su stvorena dva nacionalna politička bloka. U jednom su bili vijećnici hrvatske nacionalnosti iz HDZ-a i Hrvatske demokratske stranke (HDS), a u drugom vijećnici srpske nacionalnosti iz SDS-a i SKH-SDP-a. No, Benkovac je prema planovima SDS-a bio važna općina koja je trebala pripadati novoj $\mathrm{ZO}$ koju su počeli graditi te se nije

59 Miran i zajednički suživot, Oslobođenje, br. 15132, 5. 8. 1990., 2.

60 I aplauz, i incident, Oslobodenje, br. 15138, 11. 8. 1990., 4.

${ }_{61}$ SDS BiH broji 250 hiljada članova, Oslobodenje, br. 15139, 12. 8. 1990., 3.

62 MKSJ, Martić (IT-95-11), Zaključak o pokretanju inicijative za osnivanje ZO Sjeverne Dalmacije i Like, Knin, 6. 6. 1990., Klasa 021-05/90-02/54, Ur. broj 2136-01-90-1, potpis: Predsjednik M. Babić, pristup ostvaren 20.9. 2016., http://icr.icty.org/bcs/defaultb.aspx.

63 Izabran samo predsjednik, Narodni list, br. 2005, 16. 6. 1990., 6.

64 SDS uživa ugled među Srbima, Narodni list, br. 2007, 30. 6. 1990., 12. 
smjelo dopustiti da predsjednik općine nije iz redova SDS-a. ${ }^{65}$ Slično političko stanje onomu u Benkovcu bilo je i u općini Glina. Međutim, tu je ipak postignut hrvatsko-srpski politički dogovor. Uz potporu vijećnika HDZ-a i HDS-a, za predsjednika SO Glina izabran je Velibor Matijašević iz SDS-a. ${ }^{66}$

Sabor SR Hrvatske rad je nastavio sjednicom koja je trajala od 26. do 28. lipnja 1990. Na dnevnom redu bila je rasprava o promjeni Ustava SR Hrvatske. Cilj predloženih amandmana bio je ojačati suverenost Hrvatske i hrvatskog naroda te početi s dekomunizacijom društva kroz ukidanje komunističkih simbola i atributa. Sjednici su prisustvovali i zastupnici SDS-a. ${ }^{67}$ Usporedno s održavanjem saborske sjednice, vijećnici SO Knin su 27. lipnja 1990. usvojili odluku o konstituiranju ZO Sjeverne Dalmacije i Like sa sjedištem u Kninu. Prema odluci, novoosnovanu ZO trebale su činiti općine Knin, Benkovac, Gračac, Donji Lapac, Obrovac i Titova Korenica. Također, u odluci je bila opcija koja je omogućavala pristupanje i drugih hrvatskih općina. K tomu, odluka o osnivanju ZO na snagu je stupala onda kada je najmanje dvije općine usvoje u istom tekstu te su radi upravljanja novoosnovanom ZO osnovani Skupština ZO i njezino Privremeno Predsjedništvo. ${ }^{68}$

Prva sjednica Privremenog predsjedništva ZO Sjeverne Dalmacije i Like održana je 3. srpnja 1990. u Kninu. Doneseno je više odluka. Za predsjednika Privremenog predsjedništva izabran je predsjednik SO Knin M. Babić. Također, općine u kojima je SDS ostvario izbornu pobjedu usvojile su odluku o osnivanju i pristupanju ZO Sjeverne Dalmacije i Like. Također, odlučeno je da se službeno u novoosnovanu ZO pozovu i ostale hrvatske općine naseljene srpskim stanovništvom. Sukladno tomu, čelnici iz tih općina pozvani su na novi sastanak u Knin koji je zakazan za 6. srpnja $1990 .{ }^{69}$

Dogovoreni sastanak održan je 6. srpnja 1990. u Kninu. Sastanku su nazočili predstavnici hrvatskih općina s navodno većinskim srpskim stanovništvom te J. Rašković, D. Zelembaba, J. Opačić i Dušan Starević. Na dnevnom redu bilo je postizanje zajedničkog dogovora o daljnjem ustroju i širenju ZO Sjeverne Dalmacije i Like te zauzimanje stajališta prema predloženim ustavnim

65 Općina visokog rizika, Slobodna Dalmacija, br. 14205, 20. 6. 1990., 14.

66 Marko SREMIĆ, Glina u razdoblju od godine 1990. - 1997., Državnost: Časopis za politiku,znanost, kulturu i gospodarstvo, br. 3, Zagreb, 1997., 351 - 362.

67 Izvješća hrvatskog Sabora, Vjesnik, br. 15370, 5. 7. 1990., 13 - 18.

68 MKSJ, Martić (IT-95-11), Odluka o osnivanju i konstituisanju ZO Sjeverne Dalmacije i Like, Knin, 27. 6. 1990., Klasa 021-05/90-02/68, Ur. broj 2136-01-90-1, potpis: Predsjednik M. Babić, pristup ostvaren 20. 9. 2016., http://icr.icty.org/bcs/defaultb.aspx.

69 Republika Hrvatska i Domovinski rat 1990.-1995., Knjiga 2, Dokumenti institucija pobunjenib Srba u RH 1990.-1991., 33 - 35. 
amandmanima..$^{70}$ Međutim, nisu svi bili zadovoljni s postignutim dogovorima na sastanku. Predsjednik SO Titova Korenica Dragomir Đević iz SKH-SDP-a ubrzo je demantirao najavljeno pristupanje svoje općine u novu ZO te je ustvrdio da je sastanku prisustvovao samo lokalni predstavnik SDS-a. ${ }^{71}$ Uslijedila je reakcija SDS-a u Titovoj Korenici. Na skupštini koju su održali 12. srpnja 1990. raspravljali su o sadržaju amandmana na ustav SRH te o potrebi priključenja njihove općine ZO Sjeverne Dalmacije i Like. No, donesen je zaključak da se uputi zahtjev općinskim vlastima u kojem se kao potreba vidjelo priključenje novoosnovanoj ZO. ${ }^{72}$ To nije bio izolirani slučaj. I predsjednik SO Vukovar Slavko Dokmanović javno je prozvan iz vukovarskog SDS-a zbog nedolaska na kninski sastanak. No, on im je odgovorio da nije išao u Knin jer Vukovar nije općina većinski naseljena srpskim stanovništvom te da je on član SKH SDP-a. ${ }^{73}$ Nasuprot tomu, SO Obrovac usvojila je 12. srpnja 1990. očekivanu odluku o pristupanju ZO Sjeverne Dalmacije i Like. Glasovanje je podijelilo općinske vijećnike po nacionalnoj pripadnosti. ${ }^{74}$

Unatoč tomu što je SDS donio niz nezakonitih odluka u općinama u kojima je obnašao vlast, hrvatske vlasti pokušavale su doći do mirnog rješenja. $\mathrm{Na}$ prijedlog predsjednika F. Tuđmana održan je u Zagrebu 16. srpnja 1990. sastanak predsjednika Sabora Ž. Domljana s predsjednicima svih hrvatskih općina. Glavne teme tijekom sastanka bile su politički događaji u Kninu i problemi u međusobnoj komunikaciji. Ž. Domljan ponovio je spremnost hrvatskih vlasti na suradnju sa svim političkim opcijama te je ocijenio „uzaludnim pokušaj stvaranja srpskih autonomija“. Međutim, izgleda da poruka nije dobro prihvaćena. Predsjednik SO Knin M. Babić odmah je odbacio ponudu, te je poručio da se „nikada neće pristati“ na ustavne amandmane koji Srbima uzimaju „status suverenog naroda“ ${ }^{75}$ Nakon toga su i na području Banovine u režiji politike SDS-a uslijedila pristupanja tamošnjih općina u ZO Sjeverne Dalmacije i Like. Vijećnici SO Dvor na Uni usvojili su 17. srpnja 1990. odluku o pristupanju. ${ }^{76}$ I vijećnici SO Glina su 24. srpnja 1990. donijeli odluku o pristupanju u ZO Sjeverne Dalmacije

70 Branimo se od udarca na srpsko nacionalno biće, Politika, br. 27568, 7. 7. 1990., 9.

71 Protiv osnutka srpske krajine, Večernji list, br. 9656, 8. 7. 1990., 4.

72 Jovan Rašković neće na Jazovku, Vjesnik, br. 15378, 13. 7. 1990., 2.

73 Dva tabora u Berku, Politika, br. 27573, 12.7. 1990., 13.

74 Obrovac u kninskoj zajednici, Slobodna Dalmacija, br. 14428, 13. 7. 1990., 2.

75 Žarko Domljan, Visoko podignimo zastavu, Hrvatska - od negacije do priznanja, Zagreb, $2010 ., 118$ $-119$.

76 Republika Hrvatska i Domovinski rat 1990.-1995., Knjiga 2, Dokumenti institucija pobunjenih Srba u RH 1990.-1991., 38 - 39. 
i Like. Odluku su samostalno donijeli vijećnici srpske nacionalnosti, nakon što su vijećnici hrvatske nacionalnosti napustili sjednicu. ${ }^{77}$

Ubrzo se u Zagrebu 23. srpnja 1990. održao još jedan sastanak na kojem se pregovaralo o mirnom rješenju novonastale političke krize. Sudionici sastanka bili su F. Tuđman, njegov savjetnik Slaven Letica i J. Rašković. ${ }^{78}$ No, vrlo brzo je J. Rašković u beogradskom dnevnom listu Politika iznio svoju interpretaciju razgovora. U njoj je tvrdio da je „lagani optimist“ jer mu je F. Tuđman navodno rekao da je „za zapis“ u Ustavu prema kojem je Hrvatska „država Hrvata i Srba“. Usto, navodno je upozorio F. Tuđmana da „pravo na odcjepljenje imaju narodi, a ne države“ te mu je najavio „odcjepljenje Srba iz Hrvatske“ ako bi se dogodio „raspad Jugoslavije“ ${ }^{79}$

Unatoč Raškovićevu optimizmu, na sjednici Sabora održanoj 25. i 26. srpnja 1990. izglasovani su ustavni amandmani. Tom odlukom započelo je ispunjavanje pobjedničkog programa HDZ-a. Usvojeni amandmani jačali su suverenost Hrvatske i hrvatskog naroda te je započela dekomunizacija društva kroz ukidanje službenih komunističkih simbola i atributa. Također, pokrenut je postupak za izradu novog demokratskog Ustava RH te je ukinuta zakonska mogućnost povezivanja hrvatskih općina u ZO. ${ }^{80}$

Politički odgovor SDS-a na odluke Sabora bila je organizacija Srpskog Sabora 25. srpnja 1990. u Srbu. Službeni organizator događaja je bilo Predsjedništvo ZO Sjeverne Dalmacije i Like. Srpski sabor proglašen je političkim predstavnikom svih hrvatskih Srba, dok je kao njegov izvršni organ konstituirano Srpsko nacionalno vijeće (SNV). Također je usvojena „Deklaracija o suverenosti i autonomiji srpskog naroda" koja je sve odluke hrvatskog Sabora proglasila ništavnim. ${ }^{81}$

No, najuže vodstvo SDS-a u stvari je bilo glavni organizator Sabora. Neposredno prije održavanja vijećnici SO Knin donijeli su odluku da se 25 . srpnja 1990. proglašava neradnim danom. Razlog je bio želja da u Srbu bude prisutno što više građana. ${ }^{82}$ Također, iako su društvena poduzeća s područja općina Knin, Obrovac i Benkovac tada bila u velikim financijskim problemima, radnici su dobili financijsku pomoć i slobodan dan za odlazak u Srb. Stoga se

77 Glina mijenja ZO, Večernji list, br. 9635,, 25. 7. 1990., 7.

78 Prava da, autonomija ne, Vjesnik, br. 15390, 24. 7. 1990., 1.

79 Tuđman: Brisati Zajednicu opština, Politika, br. 27586, 25. 7. 1990., 10 - 11.

80 D. KNEŽEvić, Hrvatska demokratska zajednica, od osnivanja do raskida s Jugoslavijom, 230 - 231.

81 Republika Hrvatska i Domovinski rat 1990.-1995., Knjiga 2, Dokumenti institucija pobunjenih Srba u RH 1990.-1991., 39 - 44.

82 Poništena počast Vladimiru Bakariću, Slobodna Dalmacija, br. 14326, 21. 7. 1990., 32. 
postavljalo logično pitanje odakle navedena sredstva. ${ }^{83} \mathrm{O}$ ulozi vodstva SDS-a pri organizaciji Sabora svjedočio je kasnije J. Opačić. Prema tom svjedočenju, istaknuti članovi vodstva SDS-a su se uoči skupa sastali u lokalnom motelu u Srbu. No, odmah je došlo do sukoba nakon što je M. Babić zabranio njemu i D. Zelembabi da govore na skupu. Na kraju je sukob osobno izgladio J. Rašković. Također, ustvrdio je da su odluke donesene na Saboru u Srbu bile pogrešne te da je „Deklaracija o suverenosti i autonomiji srpskog naroda“ trebala biti samo pritisak na hrvatske vlasti, a ne službeni dokument. Usto, on je tražio da Deklaraciju sastave najjači pravni eksperti iz redova srpskog naroda. Međutim, M. Babić je taj posao povjerio lokalnom kninskom pravniku Dušanu Vještici kao svom čovjeku od povjerenja. ${ }^{84} \mathrm{U}$ Srbu se na kraju okupio veliki broj ljudi uz već poznatu velikosrpsku ikonografiju. Na skupu je bio i prisutan opozicijski srbijanski političar i četnički vojvoda Vojislav Šešelj sa svojom pratnjom. ${ }^{85}$

Prva sjednica SNV-a održana je 31. srpnja 1990. na kninskoj tvrđavi. Za predsjednika je izabran M. Babić, dok su za potpredsjednike izabrani predsjednik SO Donji Lapac David Rastović i čelnik Jugoslavenske samostalne demokratske stranke (JSDS) Mile Dakić. Za sekretara je izabran Dušan Vještica. Izglasovan je i poslovnik SNV-a. U zaključku SNV-a odbačeni su usvojeni amandmani na hrvatski Ustav te je donesena odluka o skoroj organizaciji referenduma o autonomiji hrvatskih Srba. ${ }^{86}$ Bio je to još jedan politički uspjeh M. Babića. On je kasnije svjedočio o svom izboru na čelo SNV-a. Prema Babiću, uoči prve sjednice SNV-a posjetio je J. Raškovića u Primoštenu jer je navodno želio da on vodi SNV. No, J. Rašković odbio je tu ponudu te mu je predložio da ipak on preuzme SNV. Međutim, i ovom se kadrovskom rješenju ponovno najviše protivio J. Opačić jer je smatrao da je cijela zamisao oko osnivanja $S N V$-a bila njegova. ${ }^{87}$ Prema Opačićevu svjedočenju, on nije imao osobnih ambicija u SNV-u. U stvari, bio je nezadovoljan sastavom SNV-a koji im je prezentirao M. Babić. U sastavu SNV-a nije vidio puno uglednih ljudi te je smatrao da bivši komunisti opet tumače interese Srba u Hrvatskoj. No, J. Rašković je tijekom sjednice javno dao podršku M. Babiću te je odbacio sve prigovore članova koji su tvrdili da je SNV paralelno tijelo vlasti. ${ }^{88}$

83 Nema za plaće - ima za miting, Večernji list, br. 9636, 26. 7. 1990., 6.

84 J. OpAčıć, Tragedija krajiških Srba, 128 - 131.

85 Rašković: Ovo je ustanak bez oružja, Slobodna Dalmacija, br. 14241, 26. 7. 1990., 7.

86 Republika Hrvatska i Domovinski rat 1990.-1995., Knjiga 2, Dokumenti institucija pobunjenib Srba u RH 1990.-1991., 47 - 56.

87 MKSJ, Babic (IT-03-72), Razgovor Milana Babića s haaškim istražiteljima vođen 27. 11. 2001., 31 - 33, pristup ostvaren 15. 9. 2016., http://icr.icty.org/bcs/defaultb.aspx.

88 J. OpAČıć, Tragedija krajiških Srba, 131 - 133. 
U međuvremenu, u zagrebačkom tjedniku Danas objavljen je cjelokupni transkript razgovora s tajnog sastanka F. Tuđmana i J. Raškovića. Transkript je plasiran na osnovi odluke predsjednika F. Tuđmana i njegova savjetnika Slavena Letice. Toj su odluci vjerojatno presudili Raškovićevi stalni kontradiktorni istupi, koji su ovisili o okruženju njegovih istupa. ${ }^{89}$ Objava je uzburkala politički život u Hrvatskoj, posebno zbog dijela Raškovićevih razmišljanja. U transkriptu se jasno vidjelo Raškovićevo ograđivanje od skupa u Srbu i negativna ocjena Miloševićeve politike. Priznao je i postojanje četničke ideologije među svojima političkim pristašama. Također se ogradio od navodne žrtve atentata Miroslava Mlinara i njegovih veza s četničkim vojvodom u emigraciji popom Momčilom Đujićem. Ipak, posebno je bila osjetljiva Raškovićeva psihološka ocjena da su „Srbi lud narod“. 90

Objava i sadržaj transkripta izazvali su veliko nezadovoljstvo unutar vodstva SDS-a. Stoga je dio ljudi iz inicijativnog Glavnog odbora SDS-a zatražio Raškovićevu ostavku. Raškovićevu ostavku zatražili su J. Opačić, Rodoljub Bjelanović, Marko Dobrijević i Branko Perić. No, oni nisu bili jedini koji su to zahtijevali. Kad je došao kod Raškovića u Primošten razgovarati o tome tko će biti predsjednik SNV-a, M. Babić zatekao je i Krstu Bijelića, tadašnjeg novinara TV Beograd. On je navodno već pripremio vijest o Raškovićevoj ostavci te je pomogao grupi koja je tražila Raškovićevu ostavku plasirati transkript s Tuđmanom u beogradski tjednik Dugu. ${ }^{91} \mathrm{~S}$ obzirom na poznati Miloševićev utjecaj na srbijanske medije, Bijelićeva uloga u pokušaju Raškovićeve smjene ukazivala je na to da je smjena na čelu SDS-a samo pitanje vremena. ${ }^{92}$

Objava transkripta i pokušaj Raškovićeve smjene potaknuli su izvanredni sastanak vodstva SDS-a koji je održan 7. i 8. kolovoza 1990. u Kninu. Tema je bila Raškovićeva smjena. Na kraju je J. Rašković ipak uspio izbjeći smjenu. Krajnji zaključak okupljenih bio je da ima podršku stranke unatoč sadržaju transkripta, koji su ocijenili kao „podvalu HDZ-a i Tuđmana“.93 Prema Opačićevu svjedočenju, na sastanku su on i D. Zelembaba zatražili Raškovićevu ostavku zbog slabe organizacije stranke i građenja njegova kulta ličnosti te zbog navoda iz transkripta. Nakon što su njihovi zahtjevi odbijeni, podnijeli su ostavke na sve stranačke funkcije. No, J. Rašković zamolio ih je da povuku ostavke jer je

\footnotetext{
89 Novi beogradski mit - Velika Srbija mirnim putem, Hrvatski list, br. 307, 12. 8. 2010., 33.

90 Nikica BARIĆ, Srpska pobuna u Hrvatskoj, 1990-1995., Zagreb, 2005., 70 - 71.

91 MKSJ, Babic (IT-03-72), Razgovor Milana Babića s haaškim istražiteljima vođen 27. 11. 2001., 32, pristup ostvaren 15. IX. 2016., http://icr.icty.org/bcs/defaultb.aspx.

92 Opširnije vidi u Borisav Jović, Knjiga o Miloševiću, Beograd, 2001., 13.

93 Tuđmanova neuspela podvala, Politika, br. 27601, 9. 8. 1990., 7.
} 
bio zabrinut zbog moguće polarizacije u stranci. Ipak, bilo je nekih promjena $u$ vodstvu stranke. Za novog glavnog sekretara SDS-a izabran je Marko Dobrijević. Tom kadrovskom odlukom dodatno je ojačan Babićev položaj u stranci jer je M. Dobrijević bio osoba od Babićeva povjerenja. ${ }^{94}$

Političko se stanje zbog djelovanja SDS-a početkom kolovoza 1990. dodatno radikaliziralo i na području Korduna i Banovine. Razlog je bila želja vodstva SDS-a da što prije preuzme vlast i u tamošnjim općinama. Zbog toga je u službeni posjet tom području došao hrvatski ministar unutarnjih poslova Josip Boljkovac, kojeg su službeno pozvali predsjednik SO Vojnić Vladimir Košarić i predsjednik SO Vrginmost Dmitar Obradović. Inače, navedeni lokalni čelnici bili su članovi SKH-SDP-a. Tijekom sastanka D. Obradović obavijestio je J. Boljkovca o pokušaju preuzimanja općinske vlasti od strane SDS-a, iako su imali samo jednog vijećnika. Boljkovčev dolazak pratila su spontana okupljanja i prosvjedi u organizaciji SDS-a. Nakon toga novi pokušaj Obradovićeve smjene uslijedio je 6. kolovoza 1990. kroz ponovno „spontano“ okupljanje građana u organizaciji SDS-a. ${ }^{95}$ Nasuprot tomu, SDS je u sjevernoj Dalmaciji postigao novi politički uspjeh. Preuzeli su vlast u općini Benkovac nakon uvjerljive pobjede na dopunskim izborima. Rezultati izbora bili su putokaz za daljnje poteze. Uz potporu vijećnika srpske nacionalnosti iz SKH-SDP-a, na sjednici održanoj 7. kolovoza 1990. za predsjednika SO Benkovac izabran je Zdravko Zečević iz SDS-a. Također, donesene su odluke o odbacivanju donesenih ustavnih amandmana te o priključenju općine Benkovac u ZO Sjeverne Dalmacije i Like. Odluke su donesene bez nazočnosti vijećnika hrvatske nacionalnosti koji su napustili sjednicu. ${ }^{96}$

U međuvremenu su hrvatske institucije jasno poručivale da je najavljena provedba referenduma o srpskoj autonomiji nezakonita. Tu mogućnost nisu dopuštali ni republički, ali ni savezni zakoni. ${ }^{97}$ No, uslijedio je novi potez dijela vodstva SDS-a pod vodstvom M. Babića. Delegaciju u kojoj su bili Milan Babić, David Rastović i Bogoljub Popović je 13. kolovoza 1990. u Beogradu primio srbijanski član i predsjednik Predsjedništva SFRJ Borisav Jović. Sastanak je održan na zahtjev delegacije SDS-a. Tijekom razgovora tvrdili su B. Joviću da govore u „ime svih hrvatskih Srba“ te da "ne priznaju“ usvojene hrvatske amandmane. Sukladno tomu, došli su zatražiti od Predsjedništva SFRJ

J. OpaČIĆ, Tragedija krajiških Srba, 133 - 136.

Ministar pokrenuo lavinu, Karlovački tjednik, (Karlovac), 9. VIII. 1990., 3.

Kvorum bez Hrvata, Vjesnik, br. 15404, 8. 8. 1990., 2.

N. BARIĆ, Srpska pobuna u Hrvatskoj, 1990-1995., 75. 
„intervenciju“ u Hrvatskoj. Nakon sastanka B. Jović javno je poručio da će „upotrijebiti sva sredstva“ za zaštitu Ustava SFRJ.${ }^{98}$ Inače, ovaj sastanak održan je nakon što je M. Babić uspio osobno kontaktirati Slobodana Miloševića. Međutim, M. Babića na taj su potez potaknuli M. Martić, B. Popović i D. Rastović. Veza za kontakt s Miloševićem bio je Slobodan Jovanović, urednik beogradskog dnevnog lista Ekspres Politika. No, S. Milošević je u tom trenutku ljetovao u Hrvatskoj, stoga ih je uputio da se najprije obrate B. Joviću. Ipak, činjenica da u delegaciji nije bilo J. Raškovića bila je iznenađenje za javnost, $s$ obzirom na njegovo dotadašnje neprikosnoveno političko vodstvo u SDS-u. ${ }^{99}$ Prema J. Opačiću, ovim sastankom pokazano je tko su u stvari politički favoriti vrha Srbije u vodstvu SDS-a. ${ }^{100}$ Treba reći da je uključivanje srbijanske politike u snažnije moderiranje odnosa u SDS-u tek u kolovozu 1990. bilo uvjetovano situacijom u kojoj su srbijanski komunisti pritisnuti općom demokratizacijom bili zaokupljeni transformacijom u Socijalističku pariju Srbije (SPS), kao i najpogodnijim vremenom po njihove interese u kojem bi se održali demokratski izbori. Osim toga, ponovno se pogoršalo sigurnosno stanje na Kosovu, gdje su Albanci pod pritiskom srbijanske represije proglasili Republiku Kosovo. ${ }^{101}$

Nakon sastanka $s$ B. Jovićem objavljen je i veliki razgovor M. Babića $s$ novinarima beogradske Politike. Navedene novine bile su već dugi niz godina u potpunosti na liniji politike vodstva Srbije. U razgovoru je M. Babić jasno iznio da „nema rascjepa“ te je demantirao „utjecaj četničke ideologije“ unutar SDS-a. Također je istaknuo da je SDS „stranka lijeve orijentacije“. Potvrdio je i traženje autonomije za hrvatske Srbe te je poručio da ne žele u „službenoj upotrebi hrvatski jezik i hrvatske simbole“. Osim toga, novinar je na Babićevu stolu primijetio srpsku zastavicu s Raškovićevim likom, nakon čega je zaključio da je ovakav fenomen „kulta ličnosti već viđen“. Na taj novinarski komentar M. Babić odgovorio je da je u stvari taj „kult skoro doveden do apsurda“. Navedeni Babićev odgovor je bio nagovještaj nekih novih odnosa snaga unutar stranke. ${ }^{102}$

Druga sjednica SNV-a održana je 16. kolovoza 1990. u Dvoru na Uni. Sjednicom je predsjedavao M. Babić, koji je okupljene obavijestio o beogradskim razgovorima $s$ B. Jovićem. Također, istaknuo je da je dobio Jovićevu potporu za političku borbu hrvatskih Srba i održavanje referenduma za uspostavu

98 Predsedništvo SFRJ koristiće sva prava i sredstva da spreči međunacionalne sukobe, Politika, br. 27606, 14. 8. 1990., 1.

99 Milošević vs Jugoslavija, knjiga II, prir. Sonja Biserko, Beograd, 2004., 721.

100 J. Opačić, Tragedija krajiških Srba, 136.

101 Borisav Jović, Posljednji dani SFRJ, Kragujevac, 1996., 152 - 153, 162, 170.

102 Sva rešenja osim demokratskih su ludost, Politika, br. 27607, 15. 8. 1990., 10. 
autonomije. No, navodno je dobio potporu i od vrha JNA za političko djelovanje SDS-a. Sve Babićeve navode potvrdio je predsjednik SO Donji Lapac D. Rastović, koji je također istaknuo da je JNA „garant njihovih odluka“. Saborski zastupnik SDS-a D. Ergarac pozdravio je razgovore $s$ Beogradom, kao i iniciranje pitanja „odcjepljenja“ od Hrvatske. Na kraju sastanka usvojena je odluka o datumu održavanja referenduma o autonomiji Srba. Referendum se trebao provesti od 19. kolovoza do 2. rujna 1990. Usto, usvojen je zaključak da bi svi predsjednici općina s većinskim srpskim stanovništvom trebali biti članovi SNV-a. ${ }^{103}$ Nakon sastanka u javnost je plasiran i zaključak SNV-a da je rješenje Ustavnog suda RH o ukidanju ZO Sjeverne Dalmacije i Like „neustavno“ pa ih stoga ne obvezuje na provedbu. $^{104}$

U međuvremenu, SDS je ipak ostvario polovičan uspjeh u daljnjem rušenju neposlušnih predsjednika općina koje su prema njihovim projekcijama trebale pristupiti novoj ZO. Na sjednici SO Vojnić održanoj 17. kolovoza 1990. smijenjen je predsjednik SO Vladimir Košarić te je umjesto njega izabran Branko Krivokuća iz SDS-a. Smjenu je ponovno omogućio prijelaz velikog broja vijećnika iz SKHSDP-a u SDS. Navodni razlozi za smjenu Košarića bili su neodlasci u Knin na sastanke o osnivanju ZO te na Sabor u Srbu. ${ }^{105}$ Isti scenarij pokušan je u SO Vrginmost, ali je D. Obradović ipak izbjegao smjenu. Zaključak vijećnika SO Vrginmost bio je da će se inzistirati na poštivanju hrvatskih zakona. ${ }^{106}$

\section{ZNAČAJKE POLITIČKIH ISTUPA ČLANOVA VODSTVA SDS-A}

Javni istupi političara iznimno su bitni u demokratskom sustavu. Cilj takvih istupa je slanje važnih političkih poruka i stvaranje određenih političkih stavova među svojim pristašama. ${ }^{107}$ Nakon izbora članovi vodstva SDS-a svoje su političke poruke najviše plasirali na svojim velikim stranačkim skupovima. Neposredno nakon konstituiranja demokratskog Sabora održan je 3. lipnja 1990. veliki skup SDS-a u Gomirju. U svom istupu J. Rašković zamjerio je predsjedniku F. Tuđmanu što u nastupnom saborskom govoru „nije spomenuo

103 MKSJ, Martić (IT-95-11), Zapisnik II. sjednice SNV-a održanog u Dvoru na Uni 16. 8. 1990., pristup ostvaren 20. 9. 2016., http://icr.icty.org/bcs/defaultb.aspx.

104 Rješenje Ustavnog Suda Hrvatske neustavno, Oslobođenje, br. 15144, 17. 8. 1990., 19.

105 SDS preuzeo vlast, Karlovački tjednik, br. 35, 23. 8. 1990., 4.

106 Puč nije uspio, Karlovački tjednik, br. 35, 23. 8. 1990., 4.

107 Vidi u Ivan ŠIBER, Politički marketing i politički sustav, Politička misao, XXXVII/ 2, Zagreb, 2000., $149-167$. 
hrvatske Srbe“. ${ }^{108}$ Par dana poslije J. Rašković je u Zagrebu 6. lipnja 1990. održao sastanak $s$ američkim veleposlanikom Warrenom Zimmermanom. U svojim kasnijim komentarima J. Rašković tvrdio je da je navodno dobio podršku za "principe političkog rada SDS-a i srpskoga naroda“ u Hrvatskoj, ali da se nisu usuglasili u stavovima po "pitanju Kosova“. ${ }^{109}$ Čini se da je Raškovićeva interpretacija stavova veleposlanika Zimmermana trebala stvoriti javni dojam da je politika SDS-a dobila podršku SAD-a. Inače, veleposlanik SAD-a je tada u razgovorima sa svim političkim akterima u SFRJ kao američke prioritete navodio poštivanje ljudskih prava i prava manjina. Primjena ovih načela bila je povoljna za interese hrvatskih Srba, ali nepovoljna za interese Srbije na Kosovu s obzirom na katastrofalno stanje prava albanskog naroda. Stoga u tom kontekstu treba gledati Raškovićeve dvostruke kriterije u izjavi nakon sastanka. ${ }^{110}$

Na početku analiziranog razdoblja dio istupa stranačkih prvaka SDS-a bio je donekle pomirljiv prema hrvatskim vlastima. Na osnivanju odbora SDS-a u Podravskoj Slatini predsjednik odbora M. Karadžić tvrdio je da je HDZ izborni pobjednik i da stoga u "takvu volju nema nitko pravo sumnjati“. Također, pozvao je na „zajedništvo hrvatskoga i srpskoga naroda“ i lojalnost novim demokratskim vlastima. Velikim pljeskom pozdravljen je Raškovićev istup koji je iznio da „srpski narod priznaje suverenitet Hrvatske, koliko je ona spremna da prizna njegov suverenitet“ te je izrazio nadu "kako će Sabor i HDZ imati na umu želje i srpskoga naroda bez kojih nema sreće i mira u Hrvatskoj““.111 $\mathrm{Na}$ osnivanju odbora SDS-a u Vukovaru J. Rašković poručio je da ne želi biti „vođa“, već „sluga i podanik srpskoga naroda“. Za njega je Jugoslavija nastala kao „izraz slobodne volje“ te nakon što su bile „isprobane dvije“, poručio je da treba isprobati „pluralističku i demokratsku“. Osim toga, osudio je pozive iz mnoštva na Tuđmanovo ubojstvo te je zatražio „osnivanje institucija“ srpskog naroda u Hrvatskoj. ${ }^{112} \mathrm{Na}$ osnivanju odbora SDS-a u Petrinji J. Rašković poručio je da ako je na izborima "pobijedio kroatocentrizam, nije pobijedilo ustaštvo“. Također je zatražio „suverenitet srpskoga naroda“ i stvaranje „nove zajednice općina“ te „pravo na srpski jezik, nacionalne institucije i nacionalnu televiziju“. Unatoč ideološkim razlikama, uzeo je u političku zaštitu lokalnog

108 Promjene potiču srpski narod, Novi list, br. 151, 4. 6. 1990., 2.

109 Građanski suverenitet, Slobodna Dalmacija, br. 14192., 7. 6. 1990., 5.

110 Veljko KAdijević, Protiv udar: moje videnje raspada Jugoslavije, Beograd, 2010., 176 - 177.

111 Zajedništvo, bilo i ostalo sudbina, Glas Slavonije, br. 13836, 11. 6. 1990., 2.

112 Ne želimo nove grobove, Glas Slavonije, br. 13836, 11. 6. 1990., 2 - 3. 
komunističkog moćnika i svog sunarodnjaka Borislava Mikelića, koji je bio dugogodišnji generalni direktor petrinjske tvornice „Gavrilović“ ${ }^{113}$

Nasuprot tomu, iz dijela vodstva SDS-a koje je osnivalo odbore na širem zadarskom području odmah su počele dolaziti izravne prijetnje novim hrvatskim vlastima. Gosti na osnivanju odbora u Smokoviću bili su članovi vodstva SDS-a. Jedan od njih bio je Bogoljub Popović, umirovljeni oficir JNA. On je u svom istupu poručio da su u SDS-u „na putu da povežu Srbe od Jadrana do Drine, od Subotice do Kosova“ te da „snage reda“ neće dozvoliti „odcjepljenje nikoga od Jugoslavije“. Za kraj, podržao je i trenutnu politiku vrha JNA. ${ }^{114}$ Slično je govorio B. Popović na osnivanju odbora u Kuli Atlagić, kada je poručio da SDS „ne priznaje republičke granice“ te da nije „daleko dan kada ćemo se spojiti od mora do Drine“. 115

Nakon bojkota svečane sjednice zastupnici SDS-a sudjelovali su na sjednici Sabora koja je trajala od 26. do 28. lipnja 1990. No, njihov povratak u saborske klupe poklopio se $s$ početkom rasprave o usvajanju amandmana na hrvatski Ustav. Rasprava je vođena po saborskim vijećima u kojima su zastupnici SDS-a aktivno sudjelovali. Njihovi su istupi bili očekivani i temeljili su se na njihovu mišljenju da su Srbi konstitutivni narod u Hrvatskoj. U svom istupu J. Opačić podržao je „deideologizaciju grba i zastave“, ali ne samo u „funkciji izvorne samobitnosti hrvatskoga naroda“. Za njega je Hrvatska bila jedino moguća „kao građanska država ili država Hrvata i Srba“ jer je to bila hrvatska „moralna obaveza“ zbog „srpskih mučenika Drugog svjetskog rata“ te je zatražio „ravnopravnost latiničnog i ćiriličnog pisma“. Tražio je i održavanje novih izbora jer je smatrao da je SDS „druga stranka po jakosti“, ali da to nisu potvrdili na izborima zbog slabe stranačke organizacije. Tijekom svog izlaganja D. Zelembaba ocijenio je da politički „SDS ne pripada nikakvom bloku“ te je tražio da se „odgode“ ustavne promjene. U sljedećem istupu D. Zelembaba inzistirao je na dogovoru Hrvata i Srba te je poručio da ako ga ne bude - neka „Srbi grade svoju državu, a Hrvati svoju“. Osim toga, najavio je da će se hrvatski Srbi „morati ponašati“ onako kako se ponašaju narodi u „posebnim prilikama“. I Rade Tanjga tvrdio je da „srpski narod nije nacionalna manjina“ i da se Srbi „nikad neće pomiriti s tom konstatacijom“. Također, Dušan Ergarac izjasnio se

113 Za novu zajednicu općina, Jedinstvo, br. 2138, 28. 6. 1990., 2.

114 Republika Hrvatska i Domovinski rat 1990.-1995., Knjiga 2, Dokumenti institucija pobunjenih Srba u RH 1990.-1991., 28 - 30.

115 Republika Hrvatska i Domovinski rat 1990.-1995., Knjiga 2, Dokumenti institucija pobunjenih Srba u RH 1990.-1991., 30 - 31. 
protiv mogućeg konfederalnog rješenja za budući ustroj zajedničke države te je zatražio izradu saborskih radnih materijala na ćirilici. ${ }^{116}$

Nakon što je shvaćeno da HDZ neće odustati od provedbe svojih predizbornih obećanja, članovi vodstva SDS-a počeli su sve otvorenije negirati hrvatski ustavni poredak i većinsku političku volju u Hrvatskoj. Sukladno tomu, J. Rašković je 30. lipnja 1990. na osnivanju odbora SDS-a u Ličkom Osiku poručio da je odluka o osnivanju ZO Sj. Dalmacije i Like legitimna i da se ide na njezino širenje. Također, poručio je da to nije upereno protiv Hrvatske, ali da je nužno jer Hrvati „postaju povlašteni u demokratskoj Hrvatskoj“. ${ }^{117}$ Dan poslije na Dalmatinskom Kosovu održano je obnovljeno Vidovdansko zborovanje na kojem su prisustvovali velikodostojnici SPC-a i u ime SDS-a J. Rašković, M. Babić i J. Opačić. Posebno je ostao zapažen Opačićev govor u kojem je napomenuo da Srbi neće „braniti SFRJ pod svaku cijenu“ te je zaprijetio da u slučaju da SFRJ propadne - „integralna srpska država“ biti od „Like i Korduna do Pirota“ te „od Subotice do Dubrovnika“. ${ }^{118}$ Na sličnom tragu bile su izjave sudionika s kninskog sastanka na kojem se raspravljalo o daljnjem ustroju i širenju $\mathrm{ZO} \mathrm{Sj}$. Dalmacije i Like. Pa je tako J. Rašković tvrdio da se ne krije kako „su zajednice općina baze za uspostavljanje, pa čak i teritorijalnog jedinstva srpskog naroda“. $\mathrm{K}$ tomu, D. Zelembaba predložio je usvajanje zaključka u kojem se tražilo „ujedinjenje cjelokupnog srpskog naroda“, i to "posebno“ na području Hrvatske. Također, Jugoslavija je bila „moguća“ samo kao federacija, dok je uloga JNA u društvu bila „neupitna“. Usto, poručio je da „nema države Hrvatske bez srpskog naroda“, ali ako je bude - da je takvu Hrvatsku „srpski narod spreman da ruši“. ${ }^{119} \mathrm{Na}$ osnivanju odbora SDS-a u Rijeci J. Rašković ponovno je izrazio protivljenje konfederalnom rješenju za budući ustroj države. Najavio je također održavanje referenduma srpskog naroda u Hrvatskoj radi osnivanja vlastite teritorijalne jedinice te priznanje novog hrvatskog Ustava samo ako $\mathrm{u}$ njemu bude bilo „priznanje suvereniteta srpskoga naroda“ ${ }^{120} \mathrm{Na}$ središnjoj sarajevskoj osnivačkoj skupštini SDS-a u BiH J. Rašković ponovno je poručio da će hrvatski Srbi „prihvatiti novi hrvatski Ustav, koliko bude prihvatio on nas“. Zatim je J. Opačić doživio ovacije prepune dvorane zbog izjave da „srpski narod neće prihvatiti da

116 Izvješća hrvatskog Sabora, Vjesnik, br. 15370, 5. 7. 1990., 13 - 18.

117 Ne damo našu ZO, mi ćemo je širiti, Večernji list, br. 9649, 1. 7. 1990., 4.

118 Republika Hrvatska i Domovinski rat 1990.-1995., Knjiga 2, Dokumenti institucija pobunjenih Srba u RH 1990.-1991., 28 - 30.

119 Branimo se od udarca na srpsko nacionalno biće, Politika, br. 27568, 7. 7. 1990., 9.

120 Ne priznajemo grupni suverenitet, Novi list, br. 184, 8. 7. 1990., 6. 
budu nacionalna manjina u Hrvatskoj“ te javne prijetnje da ako „ne budemo imali federativnu Jugoslaviju, imati ćemo Liban. (Libanon op. a.)“." ${ }^{121}$

Inače, politički problem za vodstvo SDS-a bio je svaki službeni spomen hrvatske suverenosti. Nakon što je TV Zagreb zakonski preimenovana $u$ Hrvatsku radio televiziju (HRT), predsjednik tenjskog odbora SDS-a Ž. Čubrilo pozvao je na „neplaćanje tv pretplate“ jer je to „Hrvatska televizija, a oni su Srbi“. Osim toga, upozorio je Sabor da „im ne bi palo napamet da im miliciju obuku u već sašivene ustaške uniforme“. Pozvao je i cijeli srpski narod na jedinstvo kako bi „izborili slobodu i suverenost, odnosno bacili HDZ na koljena“ te ih „natjerati da shvate da ni u čemu nisu dostojni srpskoga naroda“. ${ }^{122} \mathrm{Za}$ SDS je problem bio i ustavna formulacija o službenom jeziku u Hrvatskoj. No, ona je bila veliki politički problem već u komunističkom sustavu. Zbog toga je Sabor SRH ustavnu formulaciju da je hrvatski književni jezik službeni jezik u SRH usvojio tek 1989. ${ }^{123} \mathrm{Zbog}$ neslaganja s tom formulacijom, iz SDS-a je sredinom srpnja 1990. upućen službeni zahtjev Ustavnom sudu SFRJ, u kojemu je traženo ispravljanje ustavne odredbe o službenom jeziku u Hrvatskoj s tvrdnjom da ona nije u skladu sa saveznim Ustavom. U obrazloženju iz zahtjeva još se tvrdilo da hrvatski Srbi nisu „spremni više podnositi“ da im službeni jezik bude „hrvatski književni jezik“. Također, najavljeno je obraćanje međunarodnim institucijama ako ne bude ispunjen njihov zahtjev. ${ }^{124}$

Iako su stalno podsjećali na veliki broj srpskih žrtava tijekom Drugog svjetskog rata, u SDS-u nisu baš bili spremni priznati žrtve iz redova drugih. Predsjednik SKH-SDP-a I. Račan predstavio je u srpnju 1990. svoj politički projekt pod imenom „Inicijativa za građansko pomirenje“. Inicijativa je predviđala zajednički posjet F. Tuđmana, I. Račana i J. Raškovića ustaškom stratištu u Glini te mjestu partizanskih pogubljenja na jami Jazovka. Nakon načelnog pristanka, J. Rašković je na kraju odbio sudjelovati u inicijativi. Svoju konačnu odluku branio je tvrdnjom da su „nepoznati“ počinitelji zločina te da se ne zna „tko su žrtve“ pronađene $u$ jami na Jazovci. ${ }^{125}$ Uskoro je u beogradskom tisku izašao komentar u kojem je inicijativa označena kao „krađa“ ideje HDZ-a o ideološkoj pomirbi hrvatskog naroda te ju je vjerojatno J. Rašković na tom tragu odbio. ${ }^{126}$

121 Demokratski odgovor srpskoga naroda, Oslobodenje, br. 15109, 13. 7. 1990., 3.

122 Traže srpsku televiziju, Glas Slavonije, br. 13860, 9. 7. 1990., 6.

123 Stjepan BABIĆ, O Deklaraciji - činjenice i pretpostavke, Kolo, Časopis Matice hrvatske za književnost, umjetnost $i$ kulturu, br. 1./2., Zagreb, 2009., 102 - 111.

124 Tužba zbog jezika, Vjesnik, br. 15377, 12.7. 1990., 2.

125 Sve je još nejasno, Vjesnik, br. 15377, 12. 7. 1990., 2.

126 Potezi koji ne iznenađuju, NIN, br. 2066, 3. 8. 1990., 18 - 20. 
Shodnočinjenici da se bližio datum usvajanja amandmana u Saboru, javni istupi članova vodstva SDS-a dodatno su se radikalizirali. U istupima se još otvorenije prijetilo amputacijom hrvatskog teritorija, dok su se postupci hrvatskih vlasti otvoreno uspoređivali s politikom Ustaškog pokreta. Na osnivanju odbora 22. srpnja 1990. u Boboti J. Rašković zaprijetio je da će hrvatski Srbi sami „posegnuti za uspostavljanjem suvereniteta“ te je iskazao spremnost „ugroziti ustaški režim u Hrvatskoj“. Zatim je M. Babić hrvatsku vlast prozvao „nacionalističkom“ te ih je optužio da su svoj „nacionalizam i ekstremizam“ prenijeli i u Sabor. ${ }^{127} \mathrm{Na}$ Saboru u Srbu J. Rašković iznio je okupljenima da je „Tuđman za dogovor“, ali je „sputan i nemoćan“, te da ovim skupom „stabiliziramo Hrvatsku, ali destabiliziramo ustašku Hrvatsku“. Nakon toga J. Opačić pozvao je okupljene na „odbacivanje“ izglasovanih ustavnih amandmana te je poručio da "priznaju Hrvatsku samo kao federalnu jedinicu slobodne i demokratske Jugoslavije“. ${ }^{128} \mathrm{Na}$ zboru SDS-a održanom 29. srpnja 1990. u Partizanskoj Drežnici J. Rašković iznio je zahtjeve što se tiče političke budućnosti Hrvatske. Treba reći da su bili izneseni u ultimativnoj formi. Istaknuo je tako da će „ako Hrvatska ostane u federativnoj Jugoslaviji, zahtjevi hrvatskih Srba biti minimalni“, a da ako dođe do uspostave konfederacije hrvatski će Srbi „tražiti političku autonomiju“. Međutim, ako dođe do „odcjepljenja Hrvatske organizirati će referendum na kojem će sami odlučiti što žele“. ${ }^{129}$ Početkom kolovoza 1990. na osnivanju odbora SDS-a u Prijedoru ponovno je J. Rašković osudio donesene hrvatske ustavne amandmane jer "ne vode putevima demokracije“. Usto, Sabor je ocijenio kao „tiranski parlament“ pa je shodno tomu politika hrvatskih Srba bila samo „odgovor“ na te poteze. ${ }^{130} \mathrm{Na}$ osnivanju odbora 9. kolovoza 1990. u Mirkovcima J. Rašković tvrdio je da Srbi „ne pristaju“ na „doziranje slobode“. Također, Sabor je ocijenio kao ,instrument HDZ-a“ koji ima „antisrpske i srbofobne tradicije“ te da politika SDS-a ne „destabilizira Hrvatsku, nego ustaštvo“. Nakon njega predsjednik mirkovačkog odbora SDS-a M. Ćirić poručio je da u SDS-u neće dozvoliti da se zatre „srpsko ime i da to učine povampireni duhovi Radića, Starčevića i ustaša." ${ }^{131}$

Unatoč poznatoj činjenici da su Srbi u natprosječnom broju bili zastupljeni u članstvu i upravljačkim strukturama SKH i SK BiH, politike ovih partija također su bile metom napada iz SDS-a. Inače, J. Rašković bio je znan kao protivnik komunističke ideologije te je dugogodišnju političku vladavinu hrvatskih

127 Štit i mač Srba, Glas Slavonije, br. 13872, 9. 7. 1990., 12.

128 Rašković: Ovo je ustanak bez oružja, Slobodna Dalmacija, br. 14241, 26. 7. 1990., 7.

129 Tuđmanu je stalo do mira, Novi list, br. 206, 30. 7. 1990., 3.

130 Zamjerke Skupštini SR BiH, Oslobođenje, (Sarajevo), 3. VIII. 1990., 3.

131 Mržnja se mora stišati, Glas Slavonije, br. 13888, 10. 8. 1990., 15. 
komunista i Vladimira Bakarića otvoreno vidio lošom za interese hrvatskih Srba. ${ }^{132}$ Sukladno tomu, SO Knin je u srpnju 1990. donijela odluku o oduzimanju titule počasnog građanina koju je imao V. Bakarić. ${ }^{133}$ I komunističke vlasti SR BiH bile su metom napada nakon što je zakonski zabranjen prvi skup SDS-a u BiH. Unatoč tomu, skup je održan. No, J. Rašković javno je ocijenio zabranu „sramnim činom sistema i jednopartijske države “. ${ }^{134}$ I savezni premijer Ante Marković našao se izložen napadima iz SDS-a. Razlog je bilo Markovićevo osnivanje stranke pod imenom Savez reformskih snaga Jugoslavije (SRSJ), koja je smatrana velikim političkim suparnikom u SDS-u BiH. ${ }^{135}$ Stoga nije bilo iznenađenje kada ga je J. Rašković napao na skupu SDS-a u Mrkonjić Gradu. U napadu je otvoreno aludirao na Markovićevo hrvatsko podrijetlo te mu je poručio da je „takvu stranku mogao da osnuje samo u Lištici“. ${ }^{136}$ I sekretar SDS-a za Vojvodinu Ilija Končarević ubrzo je poslao sličnu poruku saveznom premijeru. Na skupu u Mirkovcima poručio je da ,još nijedan Ante nije Srbima donio sreću, pa neće ni ovaj“. ${ }^{137}$

Vrh komunističke JNA ipak je bio pošteđen od napada iz vodstva SDS-a. Unatoč ideološkim razlikama, politika JNA za SDS nije predstavljala problem. Od njih se ipak očekivalo da podupru politička nastojanja SDS-a jer su im nove hrvatske vlasti bile zajednički neprijatelj. ${ }^{138}$ Međutim, ovo savezništvo nije čudilo $s$ obzirom na natprosječan udio kadrova srpske nacionalnosti unutar JNA i njihovu dominaciju koja je dugo i smišljeno građena u SFRJ. ${ }^{139}$

\section{ULOGA ČLANOVA SDS-A U POČETKU SRPSKE POBUNE U HRVATSKOJ}

Nakon oduzimanja oružja hrvatske TO snage unutarnjih poslova postale su jedini resor obrane koji je po zakonu bio pod kontrolom novih hrvatskih vlasti. Unatoč poznatoj činjenici o nepovoljnoj nacionalnoj strukturi zbog prekobrojnog

132 Jovan RAšKović, Luda zemlja, Beograd, 1990., 161., 171 - 172.

133 Poništena počast Vladimiru Bakariću, Slobodna Dalmacija, (Split), 21. VII. 1990., 32.

134 Rašković promovisao stranku, Oslobođenje, br. 15101, 5. 7. 1990., 4.

135 B. Plavšić, Svedočim, 28, 43 - 44.

136 Liderima zasmetala Markovićeva stranka, Oslobođenje, (Sarajevo), 3. VIII. 1990., 3.

137 Mržnja se mora stišati, Glas Slavonije, br. 13888, 10. 8. 1990., 15.

138 MKSJ, Martić (IT-95-11), Zapisnik II. sjednice SNV-a održanog u Dvoru na Uni 16. VIII. 1990., pristup ostvaren 20. 9. 2016., http://icr.icty.org/bcs/defaultb.aspx.; Republika Hrvatska $i$ Domovinski rat 1990.-1995., Knjiga 2, Dokumenti institucija pobunjenih Srba u RH 1990.-1991., 28 - 30; Ne priznajemo grupni suverenitet, Novi list, br. 184, 8. 7. 1990., 6; Za pregovore bez tenkova, Večernje novosti, br. 23944, 18. 8. 1990., 6.

139 Davor Marijan, Hrvatska 1989.-1992. Radanje države, Zagreb, 2017., 32 - 34. 
stanja Srba i ideološkoj platformi na kojoj su milicijske snage počivale, novi hrvatski ministar unutarnjih poslova J. Boljkovac je nakon stupanja na dužnost najavio laganu tranziciju sustava. Također, novi ministar bio je osoba koja je radila u komunističkom sustavu pa mu se sukladno tomu nije mogla prišiti etiketa nacionalističkog radikala u javnosti. Međutim, ni to nije pomoglo jer je 4. srpnja 1990. u beogradskom listu Politika objavljeno otvoreno pismo milicajaca iz SJS Knin koje je bilo upućeno Petru Gračaninu, saveznom sekretaru za unutarnje poslove, koji je na tu funkciju imenovan kao kadar SR Srbije. U pismu se tvrdilo da se s položaja u Hrvatskoj „smjenjuju milicajci“ srpske nacionalnosti te uvode „obilježja koja podsjećaju na NDH“. Također, potpisnici pisma najavili su svoju borbu za „narod Kninske krajine“ od kojeg su očekivali „prvo moralnu“ te ako zatreba „i drugu pomoć“. Odmah nakon objave ovog pisma u javnosti republički sekretar za unutarnje poslove Josip Boljkovac i sekretar šibenskog Sekretarijata za unutarnje poslove (SUP) Ante Bujas došli su u Knin. Navedeni nazivi njihovih funkcija bili su još uvijek recidiv prethodnog komunističkog sustava koji je uklonjen ustavnim amandmanima usvojenim krajem srpnja 1990. ${ }^{140}$

Njihov dolazak popratila su već viđena "spontana“ okupljanja građana. Sastanak sa srpske strane operativno su vodili članovi vodstva SDS-a M. Babić, J. Opačić i D. Zelembaba, dok pobunjeni milicajci nisu sudjelovali u pregovorima. Treba reći da se među pobunjenim milicajcima u svojem djelovanju ponajviše isticao inspektor Milan Martić. Predstavnici pobunjenih kninskih milicajaca zahtijevali su da nitko od potpisnika pisma ne bude suspendiran te je traženo ponovno uspostavljanje općinskog SUP-a u Kninu, odnosno izdvajanje iz jurisdikcije SUP-a Šibenika. Ministar J. Boljkovac pristao je na dio uvjeta, ali je tražio da se napiše novo pismo u kojem bi se potpisnici odrekli dijela svojih stavova. ${ }^{141}$ Hrvatska je strana na sastanku od vodstva SDS-a recipročno zatražila zapošljavanje milicajaca hrvatske nacionalnosti u SJS Knin, i to sukladno broju Hrvata u stanovništvu općine, ali za taj problem nitko sa srpske strane nije pokazao interes. To je bila zanimljiva činjenica jer se u pismu pobunjenih milicajaca tvrdilo da se oni bore za prava srpskog naroda, koji je inače tada natprosječno bio zastupljen u resoru unutarnjih poslova. Ipak, tadašnji nacionalni sastav u ovom resoru dovoljno je govorio čija su nacionalna prava i interesi bili ugroženi. No, pobuna kninskih milicajaca uz političku podršku SDS-a bila je logična. Jedinice unutarnjih poslova bile su jedine legalne naoružane jedinice pod 
upravom hrvatskih demokratskih vlasti, stoga je cilj pisma bio pokušaj SDS-a da kompromitira nove hrvatske vlasti i zaustavi promjene unutar sustava. ${ }^{142}$

Unatoč pokušajima hrvatskih vlasti da se dođe od mirnog rješenja, već opisana nelegalna politika SDS-a te najava održavanja referenduma o srpskoj autonomiji potaknule su ministra J. Boljkovca u kolovozu 1990. na ofenzivnu akciju. Na sastanku održanom 16. kolovoza 1990. ministar J. Boljkovac naredio je načelnicima iz Gospića, Šibenika, Zadra i Splita akciju izvlačenja oružja iz policijskih stanica s područja općina pod kontrolom hrvatskih Srba. No, akcija hrvatskog MUP-a nije ostala nezamijećena, pa je samo djelomično uspjela u svom naumu. Suočeni s akcijom, predsjednik SO Knin M. Babić i predsjednik SO Obrovac S. Veselinović proglasili su ratno stanje te je oružje iz policijskih stanica raspodijeljeno okupljenom stanovništvu srpske nacionalnosti koje je zatim zapriječilo prometne pravce. ${ }^{143}$ Nakon toga cestovni pravci prema Kninu zapriječeni su barikadama na kojima su naoružani civili vršili kontrolu osoba i vozila, dok je novinar savezne informativne agencije Tanjug plasirao u medije neistinitu vijest o izlasku jedinica JNA na kninske ulice. ${ }^{144}$ Po Babićevu svjedočenju, osobe koje su podizale barikade bile su uglavnom članovi lokalnih odbora SDS-a, koji su za to imali potpunu podršku lokalnog stanovništva. ${ }^{145}$ Nakon širenja pobune prema Kninu su uzletjeli helikopteri hrvatskog MUP-a radi uspostave reda i mira, ali su se zbog intervencije zrakoplova JNA morali vratiti u bazu polijetanja. Inače, namjere hrvatskog MUP-a od samog početka bile su poznate Upravi bezbednosti JNA koja je unutar hrvatskog sigurnosnog sustava imala svoje ljude. ${ }^{146}$

I na području općina Benkovac i Obrovac sigurnosno je stanje bilo slično onomu u Kninu. Uslijed toga, predsjednik SO Obrovac Veselinović javno je poručio hrvatskim vlastima da je „narod u Obrovcu izuzetno dobro naoružan“. Plasiranju prijetećih poruka potom se pridružio i predsjednik SO Benkovac Zdravko Zečević koji je zatražio smjenu ministra Boljkovca. ${ }^{147} \mathrm{Na}$ dan početka kninske pobune J. Rašković nazočio je osnivanju odbora SDS-a u Bukoviću, mjestu u općini Benkovac. U uzavreloj atmosferi i uz povike „ubit

142 Josip BolJKovac, Istina mora izaći van: sjećanja i zapisi prvog ministra unutarnjih poslova neovisne Hrvatske, Zagreb, 2009. 186., 196 - 197.

143 N. BARIĆ, Srpska pobuna u Hrvatskoj, 1990-1995., 78 - 80.

144 Srđan Radulović, Sudbina Krajine, Beograd, 1996., 20 - 21.

145 Milošević vs Jugoslavija, knjiga II, 725.

146 Izjava Radenka Radojčića, suradnika obavještajne operacije JNA pod nazivom Opera koja je realizirana tijekom srpske agresije na Hrvatsku. Izjava je dana 15. 3. 1994. Službi za zaštitu ustavnog poretka (SZUP) RH, 19. (http://www.slobodanpraljak.com/LABRADOR_F.html)

147 Specijalci iz Zadra razoružali Stanicu milicije u Benkovcu, Politika, br. 27610, 18. 8. 1990., $1 ., 5$ - 6. 
ćemo Tuđmana" od strane sudionika skupa zatraženo je da im se podijeli oružje. No, J. Rašković odgovorio im je da od njega ne trebaju tražiti oružje, ali im je poručio da ako im treba - „valjda će se naći netko tko će vam ga dati“. Također, skup su nadlijetali avioni JNA, što je nagnalo J. Raškovića da pozdravi njihov let kao "poruku s neba“ te ih je vidio kao "mirotvornu armiju“ koja „neće dizati mač na nikoga“. Inače, J. Rašković osobno nije sudjelovao u organizaciji pobune, ali je svojim političkim nastupima uvelike pripremio situaciju za njezin početak. ${ }^{148}$

$\mathrm{Na}$ dan kad je počela pobuna predsjednik SO Knin Milan Babić proglasio je ratno stanje. Ovaj čin potom je potaknuo formiranje Štaba za odbranu Knina, stacioniranog u Omladinskom naselju u selu Golubić kraj Knina. Štab je imao izravnu vezu s Centrom za obavještavanje u Kninu, koju su održavali pojedini kninski milicajci i ljudi od povjerenja kninskog političkog vodstva. Sve izvršne funkcije u Štabu odredio je Milan Babić kao komandant tog tijela. Za načelnika saniteta izabran je Dušan Zelembaba, dok je na funkciju političkog komesara izabran Jovan Opačić. Pomoćnik komandanta za pozadinu postao je Branko Perić, dok je za oficira za bezbednost izabran Nebojša Mandinić. Kninski inspektor Milan Martić, poznat iz srpanjskog pisma pobunjenih kninskih policajaca, bio je također inkorporiran kao načelnik Štaba. Sve navedene osobe bile su članovi vodstva SDS-a. Također, oružjem koje su pobunjenici nelegalno uzeli iz kninske milicijske stanice naoružano je osobno osiguranje M. Babića. ${ }^{149}$ U svojim zapisima J. Opačić potvrdio je da je M. Babić bio glavni inicijator pobune. Za njezinu provedbu dobio je podršku kninskih milicionara na čelu s M. Martićem, dok su naoružani članovi SDS-a sudjelovali u stvaranju psihoze straha kroz plasiranje lažnih informacija s terena. ${ }^{150}$

Srpski član i predsjednik Predsjedništva SFRJ Borisav Jović je na dan pobune boravio na odmoru u Crnoj Gori. Prema očekivanju, on je podržao kninsku pobunu te ju je ocijenio kao reakciju na "ponašanje hrvatskih vlasti“. Nakon eskalacije pobune odmah je telefonski razgovarao s predsjednikom $F$. Tuđmanom, sa saveznim sekretarom za obranu generalom Veljkom Kadijevićem i načelnikom Generalštaba Oružanih snaga SFRJ B. Adžićem. Članovi vojnog vrha odmah su odbacili Tuđmanove navode o pristranoj ulozi JNA tijekom

148 Za pregovore bez tenkova, Večernje novosti, br. 23944, 18. 8. 1990., 6.

149 MKSJ, Martic (IT-95-11) Izjava ovlaštenim organima bezbednosti JNA je dao Ognjen Biserko, radnik kninskog sekretarijata za Narodnu odbranu, neklasificirano, Knin, 2. 12. 1990., pristup ostvaren 20. 9. 2016., http://icr.icty.org/bcs/defaultb.aspx.

150 J. OpAČıć, Tragedija krajiških Srba, 136 - 141. 
kninskih događaja, ali se B. Joviću posebno svidio Tuđmanov „strah“ uvjetovan razvojem događaja. ${ }^{151}$ Inače, hrvatski predstavnici u saveznim institucijama odmah su zatražili potporu od saveznih institucija za snage MUP-a RH u uspostavi legalnog javnog reda i mira u Kninu. No, na taj zahtjev uzvraćeno je otvorenom prijetnjom načelnika Generalštaba generala B. Adžića da će avioni JNA napasti snage MUP-a RH ako nastave akciju. ${ }^{152}$

Ubrzo su o događajima u Kninu uslijedila službena priopćenja iz vrha JNA, Predsjedništva SFRJ i Predsjedništva SR Srbije. U svim tim priopćenjima jasno je dana podrška nelegalnom djelovanju pobunjenih hrvatskih Srba te su osuđeni legalni potezi hrvatskih demokratski izabranih vlasti. Bio je to jasan nagovještaj ponašanja JNA i politike Srbije u daljnjim događajima. Vrh JNA oglasio se preko svoga portparola pukovnika Vuka Obradovića. U priopćenju je navedeno da let jedinica hrvatske policije „nije bio najavljen“ te da je zbog toga spriječen. Također, opovrgnuo je navode hrvatskih vlasti da su snage JNA uključene u destabilizaciju R. Hrvatske te je ustvrdio da je uloga JNA u stvari „spriječiti bratoubilački rat“. Prema službenom priopćenju, jedini problem za JNA bio je navodno neprijavljeni let helikoptera hrvatskog MUP-a, ali se nisu osvrtali na činjenicu što su nepoznate osobe nelegalno preuzele službeno oružje i stvorile nelegalne formacije, zapriječile cestovne pravce i na njima vršile nezakonit pretres osoba. ${ }^{153}$ Službenim priopćenjem oglasilo se i Predsjedništvo SFRJ. U tom priopćenju B. Jović ustvrdio je da se ne može dovoditi „u pitanje pravo građana ili naroda na političko izjašnjavanje“. ${ }^{154}$ Reagiralo je pismom i Predsjedništvo SR Srbije koje je potpisao Slobodan Milošević. U pismu se navodilo da je hrvatska vlada pokušala „represivnim mjerama ukinuti Srbima ljudska prava“. Od Predsjedništva SFRJ zatraženo je da podrži zahtjeve pobunjenih Srba te da se donese savezni zakon o odcjepljenju. Svrha zakona trebala je biti da narodi Jugoslavije koji se žele odcijepiti naprave to zakonski, ali i da oni narodi koji to ne žele mogu ostati zajedno. ${ }^{155}$

Povodom događaja u Kninu, IV SO Knin održalo je izvanrednu sjednicu 18. kolovoza 1990. Nakon sjednice, u priopćenju je ustvrđeno da su kninski

151 B. Jović, Posljednji dani SFRJ, 178 - 179.

$152 \mathrm{~J}$. BoljKovaC, Istina mora izaći van: sjećanja i zapisi prvog ministra unutarnjih poslova neovisne Hrvatske, $204-205$.

153 JNA ima zadatak da spreči bratoubilački rat, Politika, br. 27611, 19. 8. 1990., 2.

154 Predsedništvo SFRJ koristiće sva svoja ustavna i zakonska prava da spreči sukobe i građanski rat, Politika, br. 27611, 19.8 1990., 2.

155 Srbija smatra svojom obavezom da svim demokratskim sredstvima pomaže Srbe u Hrvatskoj u interesu zaštite njihovih ljudskih i građanskih prava i njihove egzistencije, Politika, br. 27612, 20. 8. 1990., 1. 
događaji bili uvjetovani potezima hrvatskih državnih organa, da stanovništvo kninske općine čvrsto stoji uz zaštitu interesa i identiteta srpskog naroda te se stoga samoorganiziralo u svrhu njihove obrane. ${ }^{156} \mathrm{U}$ sličnom tonu bio je i zajednički apel Glavnog odbora SDS-a i SNV-a koji je upućen Predsjedništvu SFRJ i Saveznom izvršnom vijeću (SIV). U apelu je zatraženo da se zaustavi „divljanje državnog terora i nasilja prema srpskom narodu u Hrvatskoj“ te da se to provede „na demokratski ili drugi način“, kao i pravo da traže „demokratsku pomoć od najviših organa Jugoslavije“. ${ }^{157}$ I na ostalim hrvatskim područjima gdje je SDS bio na vlasti uslijedili su skupovi potpore kninskoj pobuni. Tako je u organizaciji lokalnog SDS-a održan veliki skup u Glini. U istupima govornika osuđena je „srbožderska politika“ hrvatskih vlasti. ${ }^{158}$

Usto, srpskoj pobuni u Kninu pristigla je podrška Srba iz drugih republika. U priopćenju SDS-a $\mathrm{BiH}$ tvrdilo se da je novi hrvatski Ustav omogućio „likvidaciju Srba“ te da su njihova prava „ugrožena“ pa će daljnje djelovanje hrvatskih organa smatrati napadom na „srpski narod u celini“. ${ }^{159}$ I Regionalni odbor SDS-a za Hercegovinu je u svom priopćenju dao potporu hrvatskim Srbima te su poručili da ako hrvatske vlasti budu zabranile referendum hrvatskih Srba, hercegovački Srbi i Jugoslavija također će biti „napadnuti“. ${ }^{160}$ Nije sve ostalo samo na verbalnoj potpori. Na područje Knina ubrzo su kao dobrovoljci pristigli članovi SDS-a iz Bosanskog Grahova i Titovog Drvara. ${ }^{161}$ I Srbi s Kosova okupljeni u udruženje „Božur“ najavili su upućivanje svojih dobrovoljaca u Knin. ${ }^{162}$

Što se tiče stajališta prema nelegalnoj pobuni u Kninu, glavne stranke iz srbijanske opozicije (Srpski pokret obnove i Demokratska stranka) nisu se razlikovale od vlasti Srbije. Za sve što se dogodilo okrivljene su hrvatske vlasti. ${ }^{163}$ Usto, D. Zelembaba otišao je korak dalje u traženju potpore unutar opozicije u Srbiji. Neposredno nakon početka pobune on je ostvario kontakt sa srbijanskim političarem i četničkim vojvodom Vojislavom Šešeljem. Cilj je

Republika Hrvatska i Domovinski rat 1990.-1995., Knjiga 2, Dokumenti institucija pobunjenih Srba u RH 1990.-1991., 56 - 58.

157 Državni teror nad Srbima, Večernje novosti, br. 23945, 19. 8. 1990., 6.

158 Ovaj narod nije više moguće ponižavati, Politika, br. 27611, 19. 8. 1990., 9.

159 Ustav Hrvatske omogućuje političku likvidaciju Srba, Politika, br. 27610, 18. 8. 1990., 7.

160 Ako hrvatska vlada upotrebi silu - i mi smo napadnuti, Politika, br. 27610, 18. 8. 1990., 6.

161 Dan teškog mira, Večernje novosti, br. 23945, 19. 8. 1990., 3.

162 Dobrovoljci za Kninsku krajinu, Politika, br. 27610, 18. 8. 1990., 6.

163 Poziv za zaštitu Srba, Večernje novosti, br. 23944, 18. 8. 1990., 4; Referendum se mora održati, Večernje novosti, br. 23944, 18. 8. 1990., 5. 
bio od V. Šešelja i njegovih političkih pristaša dobiti oružanu pomoć tijekom pobune hrvatskih Srba. ${ }^{164}$

Dva dana nakon početka pobune Glavni odbor SDS-a održao je sastanak u Kninu 19. kolovoza 1990. Glavne teme na sastanku očekivano su bili događaji u Kninu. Nakon sastanka J. Rašković potvrdio je da je razgovarao s predsjednikom F. Tuđmanom i predsjednikom Vlade S. Mesićem. Razgovori su za cilj imali smirivanje stanja. Također, ocijenio je nepotrebnim organizirani dolazak srpskih dobrovoljaca iz drugih krajeva Jugoslavije u Knin te je ponovno zatražio zaštitu od saveznih organa za Srbe u Hrvatskoj. Kao svoje ciljeve u sljedećim danima naveo je postizanje sporazuma s predsjednikom F. Tuđmanom radi smirivanja stanja te ostvarenje kulturne autonomije hrvatskih Srba. ${ }^{165}$ Međutim, bilo je onih koji nisu tako razmišljali. Nakon što su hrvatske vlasti uputile službeni zahtjev da se vrati nelegalno oduzeto naoružanje iz SJS-a, M. Babić poručio je da „nema moralno pravo da traži to od naroda“. No, navedena Babićeva izjava bila je nagovještaj stvarnih daljnjih poteza vodstva SDS-a jer je M. Babić uz potporu vodstva Srbije već uvelike od J. Raškovića preuzeo političko vodstvo unutar stranke. ${ }^{166}$

\section{ZAKLJUČAK}

U analiziranom razdoblju ključnu ulogu u osnivanju novih odbora SDS-a imao je ponovno predsjednik stranke Jovan Rašković, koji je bio prisutan na većini osnivačkih skupova u Hrvatskoj, Bosni i Hercegovini, Vojvodini i Srbiji. No, Raškovićev san da bude čelnik stranke koja djeluje među Srbima najugoslavenskoj razini tada je potpuno propao jer je odbore koje je osnivao u $\mathrm{BiH}$ morao prepustiti sarajevskoj središnjici SDS u BiH na čelu s Radovanom Karadžićem. Sličan scenarij dogodio se i s radom SDS-a u Srbiji jer je veliki broj tamošnjih članova SDS-a smatrao da ipak ne treba razvijati političku djelatnost u Srbiji i biti opozicija S. Miloševiću. U ovom razdoblju SDS je krenuo u institucionalno preuzimanje vlasti u više hrvatskih općina jer je to bio bitan preduvjet da bi se mogle donositi odluke o pridruživanju novoosnovanoj Zajednici općina Sjeverne Dalmacije i Like. Pri preuzimanju lokalnih vlasti u nekim općinama vidljiva je SDS-ova politika preglasavanja stranaka hrvatskog predznaka, i

164 Republika Hrvatska i Domovinski rat 1990.-1995., Knjiga 1, Oružana pobuna Srba u Hrvatskoj i agresija oružanih snaga i srpskih paravojnih postrojbi na Republiku Hrvatsku (1990.-1991.), Zagreb, 2007., 48.

$165 \mathrm{Ni}$ kap krvi ne sme da padne, Večernje novosti, br. 23947, 20. 8. 1990., 3.

166 Kninjani nisu prihvatili ultimatum hrvatskog vrhovništva, Politika, br. 27613, 21. 8. $1990 ., 7$. 
to bez obzira na visok udio hrvatskog stanovništva. No, to ih nije sprječavalo da od vladajućeg HDZ-a traže daleko više privilegija za brojčano puno manje zastupljen srpski narod na razini Hrvatske. Osim toga, i u općinama s visokim postotkom srpskog stanovništva počeli su rušiti neposlušna rukovodstva koja su odbijala provoditi SDS-ovu politiku. Te smjene uglavnom je omogućavao veliki broj prelazaka lokalnih vijećnika srpske nacionalnosti iz bivšeg SKH-a u redove SDS-a, i to nakon što je shvaćeno da stranka sljednica SKH-a neće imati više takav politički utjecaj kao u prošlosti. U ovom razdoblju politika SDS-a također je bila usmjerena na stvaranje nelegitimnih i paralelnih institucija koje su svojim odlukama pokušavale parirati legitimnim odlukama hrvatskih vlasti. Aktivno se djelovalo i na destabilizaciji resora unutrašnjih poslova Hrvatske jer su u SDS-u ispravno zaključili da je taj resor ostao jedina crta obrane hrvatske suverenosti.

Do izglasavanja amandmana politički istupi stranačkog vrha i članova SDS-a samo su se djelomice temeljili na već provjerenoj strategiji povezivanja novih hrvatskih vlasti s ustaškim pokretom i NDH. Stvaranjem te slike pokušalo se spriječiti promjene koje su dobile svoj legitimitet pobjedom HDZ-a na izborima, ali treba napomenuti da još postoje istupi članova stranačkog vodstva koji su težili smirivanju stanja. Razdoblje nakon usvajanja ustavnih amandmana $u$ Saboru obilježila je potpuna radikalizacija političkih istupa članova vodstva SDS-a, u kojima su dominirale tvrdnje o stvaranju „nove Nezavisne Države Hrvatske“ te "ustaškom karakteru“ i „potezima“ novih hrvatskih demokratskih vlasti. Međutim, ova provjerena strategija koja je držala hrvatsku politiku u pasivnom odnosu tijekom komunističke Jugoslavije više nije bila moguća.

Također, Jovan Rašković je u ovom analiziranom razdoblju preživio prvi pokušaj smjene s mjesta predsjednika SDS-a, a koji je bio iniciran od dijela stranačkih članova. Unatoč tomu, već se vidjelo da je M. Babić uz potporu vodstva srbijanske politike preuzeo inicijativu unutar vodstva stranke. Osim toga, unutar članstva SDS-a sve se više vidjela diferencijacija između simpatizera komunističke i četničke ideologije, ali taj proces nije dovodio u pitanje njihov zajednički negativan odnos prema novim političkim okolnostima u Hrvatskoj. Sam politički vrh SDS-a bio je bez svake sumnje inicijator i organizator početka pobune hrvatskih Srba, dok je uloga nižerangiranih članova stranka bila oružano djelovanje na terenu. Ipak, sve to se događalo uz neskrivenu političku podršku Srbije i JNA. K tomu, SDS je djelovanjem na rušenju hrvatskog ustavnog poretka izašao iz okvira normalnog političkog djelovanja pa je samim time postao teroristička organizacija i kadrovska jezgra prvih oružanih formacija pobunjenih Srba koje će sudjelovati u srpskoj agresiji na Hrvatsku. 
Domagoj KNEŽEVIĆ

SERBIAN DEMOCRATIC PARTY FROM THE CONSTITUTION OF THE FIRST MULTI-PARTY PARLIAMENT TO THE OUTBURST OF SERBIAN REBELLION IN CROATIA IN AUGUST 1990

\section{SUMMARY}

The topic of this paper is the activity of Serbian Democratic Party in Croatia from the establishment of the first multi-party Parliament to the outburst of Serbian rebellion in August 1990. The paper further tackles the establishment of party committees in other Yugoslav republics, as well as the role of leadership and party members at the beginning of Serbian rebellion. The work is based on available archive documents, testimonies and media outlets of party leaders. The secondary and tertiary sources have also been consulted, such as Croatian, Serbian, and Bosnian and Herzegovinian media, as well as available monographs about circumstances current at that time. In the analyzed period, the party leader Jovan Rašković, who was present at most founding meetings in Croatia, Bosnia and Herzegovina, Vojvodina and Serbia, played a crucial role in the establishment of new Serbian Democratic Party committees. However, his dream of becoming party leader among Serbs at Yugoslav level completely failed. In this period, Serbian Democratic Party started institutionally taking over authority in several Croatian municipalities, as this was an essential precondition for deciding on joining the newly established Community. Serbian Democratic Party policy was geared towards the creation of illegitimate and parallel institutions, which tried to match their decisions with Croatian Parliament's legitimate decisions. It was furthermore in line with the destabilization of Croatia's internal affairs, since Serbian Democratic Party correctly assessed that this line would be the first line of defence of Croatia's constitutional order and sovereignty. Additionally, there was turmoil within the party leadership. Jovan Rašković survived the first attempt, initiated by some party leaders, to shift from the presidency. However, Milan Babić overtook, supported by Serbian state politics, the leadership initiative. Within the same party, a differentiation was present between the supporters of Communist and of Chetnik ideologies. Nevertheless, this process did not question their negative attitude toward the new political circumstances in Croatia. Serbian Democratic Party itself was undoubtedly the initiator and organizer of the rebellion of the Croatian Serbs, while the role of low-rank party members was carrying out armed action in the field. All this was evidently done with the political support of Serbia and Yugoslav National Army. Additionally, 
Serbian Democratic Party stepped out of the regulal political activity by destroying Croatian constitutional order, thus becoming a terrorist organization and the core of personnel in the upcoming Serbian aggression on Croatia.

Keywords: Serbian Democratic Party; Jovan Rašković; rebellion; Milan Babić; Knin. 